九州大学学術情報リポジトリ

Kyushu University Institutional Repository

\title{
THE FAMILY CURCULIONIDAE OF JAPAN VII. GENERA COLOBODES SCHOENHERR, DERETIOSUS PASCOE AND DERETIOSOPSIS NOV. (INSECTA, COLEOPTERA)
}

Morimoto, Katsura

Entomological Laboratory, Faculty of Agriculture, Kyushu University

https://doi.org/10.5109/2505

出版情報: ESAKIA. 26，pp.39-70，1988-01-25. Entomological Laboratory，Faculty of Agriculture， Kyushu University

バージョン：

権利関係 : 


\title{
THE FAMILY CURCULIONIDAE OF JAPAN VII. GENERA COLOBODES SCHOENHERR, DERETIOSUS PASCOE AND DERETIOSOPSIS NOV. (INSECTA, COLEOPTERA)*
}

\author{
Katsura Morimoto \\ Entomological Laboratory, Faculty of Agriculture, \\ Kyushu University, Fukuoka 812, Japan
}

\begin{abstract}
The genera Colobodes and Deretiosus of Japan are revised together with description of a new genus Deretiosopsis. New taxa described in this paper are as follows : Colobodes endai sp. nov., Colobodes kuniyoshii sp. nov., Colobodes ovipennis sp. nov., Colobodes rotundicollis sp. nov., Colobodes omatoideus sp. nov., Colobodes alboguttatus sp. nov., Deretiosus ishigakianus sp. nov., Deretiosus albicaudatus sp. nov., and Deretiosopsis nigrisetis gen. et sp. nov. Deretiosus angulicollis (Heller) and Deretiosus sellatus Heller are recorded from Japan for the first time.
\end{abstract}

In continuation of my studies on the Japanese Cryptorhynchinae, I revised here the genera Colobodes Schoenherr and Deretiosus Pascoe together with a new genus Deretiosopsis as the first part of the tribe Ithyporini sensu Morimoto, 1978. Notes on the phylogeny and key to the genera of the Ithyporini will be given in the next paper.

The materials used in the present study contain 11 species for Colobodes, 4 species for Deretiosus and a species for Deretiosopsis from Japan, and some others from the tropical Asia were also studied for comparison.

The methods employed were the same as already mentioned in the part I of this series (Esakia, (19) : 52-53, 1982).

The body length was measured from the apex of elytra to the anterior margin of pronotum under a stereoscopic microscope, and the head and the fascicles were not included. The distance between the apex of rostrum and the antennal socket means the straight length from the base of the mandible to the anterior margin of the antennal socket in lateral aspect.

I heartly thank those who sent me specimens for the present study : Dr. K. Baba, Prof. M. Chajô, Mr. K. Emoto, Mr. N. Enda, Mr. H. Ichihashi, Mr. K. Iha, Mr. H. Irie, Prof. S. Kimoto, Prof. K. Kojima, Mr. S. Kuniyoshi, Prof. K. Kusama, Mr. H. Makihara, Mr. I. Matoba, Mr. T. Mikage, Dr. S. Miyakawa, Mr. Y. Miyake, Mr. Y. Miyatake, Prof. Y. Murakami, Mr. T. Ogasawara, Prof. H. Sasaji, Mr. Y. Sawada, Dr. T. Senoh, Prof. T. Shirôzu, Dr. S. Uéno and many other friends. My thanks are also due to Prof. Y. Hirashima, of Kyushu University, for his kind guidance and encouragement in the

* Contribution from the Entomolgical Laboratory, Faculty of Agriculture, Kyushu University, Fukuoka (Ser. 3, No. 251). 
course of the present study.

\section{Colobodes Schoenherr}

Colobodes Schoenherr, 1837, Gen. Sp. Curc., IV (1) : 465 (type- species : Colobodes billbergi Bo heman, by original designation). -Lacordaire, 1866, Gen. Col., VII : 57. -Roelofs, 1875, Ann. Soc. ent. Belg., XVIII : 155. -Faust, 1893, Stett. ent. Zeit., LIV : 150 (=Solobrachis). -Heller, 1921, Philipp. J. Sci., XIX (5) : 557 (key to allied genera). -Marshall, 1930, Ann. Mag. nat. Hist., (10) VI : 566 (=Aryptaeus). -Zimmerman, 1941, Occ. Pap. Bishop Mus., XVI : 186. -Morimoto, 1962, J. Fac. Agr., Kyushu Univ., 12 : 58 (key). -Morimoto, 1978, Esakia, (11) : 127 (key).

Aryptaeus Pascoe, 1882, Ann. Mag. nat. Hist., (5)X : 451 (type-species : Aryptaeus suturalis Pascoe, designated by Marshall, 1930). -Marshall, 1930, Ann. Mag. nat. Hist., (10) VI : 566 (= Colobodes).

Head densely covered with scales, sulcate along dorsal margins of eyes, vertex bare, punctate, forehead between eyes a little narrower than the base of rostrum, with a median fovea, flattened or slightly depressed ; rostrum robust to slender, carinate behind antennal insertions in male ; funicle 7 -segmented, second segment slender, longer than or subequal to first, club compact, with indefinite and arched sutures. Prothorax with ocular lobes, with two fascicles of scales at anterior margin and four fascicles in the middle, weakly produced anteriorly, but not fully covering head, shallowly bisinuate at posterior margin. Scutellum bare. Elytra broader than pronotum, with ten striae, ultimate stria weaker behind hind coxa, alternate intervals more or less fasciculate and often tuberculate or nodular, basal margins grooved for interlocking the posterior margin of pronotum in repose.

Prosternum canaliculate before coxae. Fore coxae separated. Mesostemal process slightly to steeply declivous, passing off into a plane with metasternal process between middle coxae, narrower than middle coxa. Mesosternum suddenly inflected anteriorly for receiving prothorax in general. Metasternum between middle and hind coxae as long as or shorter than first ventrite behind coxa. Hind coxae reaching metepisterna. First ventrite behind coxa as long as second and as long as third and fourth combined, first suture between first and second ventrites deeper on each side, first to sixth tergites membranous. Legs with femora clavate, fore femora often less clavate, dentate; tibiae curved at base, straight or slightly bisinuate thence to apex, carinate internally. Tarsi with third segment much wider than second, more or less notched anteriorly, claws simple, free.

Male : Rostrum more or less robuster and antenna1 insertions antemedian. First ventrite almost the same as that of female, or very slightly depressed. Abdomen with seventh tergite shallowly to deeply emarginate at posterior margin, with three to four pairs of scrapers, eighth tergite subparallelsided and broadly rounded apically. Aedeagus with internal sac of penis adorned with dense asperities, parameres widely distant.

Female : Antennal insertions median to antemedian. Abdomen with seventh tergite not emarginate, with four pairs of scrapers, eighth tergite tapered posteriorly and weakly notched at apex. Ovipositor with a pair of coxites and styli.

Solobrachis Desbrochers was synonymized with Colobodes by Faust (1893) and Hustache (1936), but was treated as an independent genus by Heller (1921) and Voss (1937), and Morimoto (1978) followed after Heller.

Thisus Pascoe is only separable from Colubodes by the separated hind coxae from the metepisterna owing to the contact of the metasternum and the first ventrite at sides, while in Colobodes, the hind 
coxae are contiguous with the metepisterna at sides.

This genus contains 23 species from the Oriental region including New Guinea, India and Japan, and 15 undescribed species are in my collection at present, of which 6 from Japan are described in this paper.

\section{KEY TO JAPANESE SPECIES}

1(2) First and second ventrites with sparse punctures, interstices between punctures almost as wide as their diameters, each puncture with a small narrow hair-like scale. Pronotum with a median keel before the middle. Scaling concolorous ash brown to brown, fascicles on pronotum consisting of loose small erect scales. Length : 5.0-6.2 mm. Honshu.

Colobodes endai sp. nov.

2(1) First and second ventrites with dense scales almost concealing derms. Pronotum without median keel.

3(4) Elytra oval, with oblique humeri, humeral calli lying on a level of subbasal fascicles. Mesosternum not suddenly inflected anteriorly for receiving prothorax, but continuously sloped in a curve. Scaling predominantly ash brown, with a subtriangular blackish median common patch ranging from sides of median tubercles on third interval to scutellum, with indefinite greyish median and lateral stripes on pronotum and a transverse band along hind margin of median patch. Hind wings atrophied. Length : 4.7-5.2 mm. Kyushu.

Colobodes ovipennis sp. nov.

4 (3) Elytra with rectangular humeri, humeral calli lying much anterior to the level of subbasal fascicles.

5(8) Tibiae triangularly dilated outwards near base.

6 ( 7 ) Elytra weakly and evenly rounded at sides, broadest at third from base, with blackish oblique band combining second fascicles on third and fifth intervals, and blackish at the bases of second, fourth and sixth intervals, second fascicles located at basal third. Pronotum broadest at basal third, evenly rounded at sides. Metasternum between middle and hind coxae as long as third ventrite. Hind wings atrophied. Length : 6.0-6.6 mm. Ishigaki, Iriomote, Taiwan.

Colobodes rotundicollis sp. nov.

7 (6) Elytra parallel-sided on basal half, second fascicle on third interval median, without blackish band. Pronotum parallel-sided on basal half. Metasternum between middle and hind coxae longer than third ventrite, but shorter than second ventrite. Hind wings normal. Length : 5.5-6.2 mm. Honshu, Kyushu.

8(5) Tibiae not distinctly expanded externally near base, but almost of the same width throughout.

9(14) Body robuster, pronotum 1.2-1.5 times as wide as long. Elytra narrowly fringed with whitish scales at basal margin, third interval tapered basally, curved inwards and greyish to whitish before subbasal fascicle.

10 (11) Basal area of elytra broadly greyish between humeri and exterior half of third intervals, subbasal fascicle on third interval partly blackish or entirely brownish. Third fascicle on third interval behind middle consisting of greyish and brownish scales, smaller than the second. Length : 5.7-7.1 mm. Hachijo, Tokaras (Akuseki, Kuchinoshima, Nakanoshima), Amami-Oshima, Tokunoshima, Okinawa.

Colobodes ornatoideus sp. nov.

11(10) Basal area of elytra before subbasal fascicles greyish or paler on third and fifth intervals and humeri, other intervals darker, subbasal fascicle on third interval 
almost blackish, third fascicle on third interval behind middle much larger than the second and purely greyish.

12(13) Tibiae angulate externally at basal third. Elytra with a V-shaped common greyish to whitish patch combining third fascicles on third intervals. Mesostemum with a small tubercle on each side before middle coxa. Length : 6.0-7.8 mm. Honshu, Kyushu, Tsushima, Yakushima......

Colobodes ornatus Roelofs

13(12) Tibiae roundly curved at basal fourth. Elytra with third fascicle on third interval conspicuous, oval and whitish. Mesostemum scarcely tuberculate on each side before middle coxa. Length : $6.8-8.3 \mathrm{~mm}$. Ishigaki, Iriomote.

Colobodes alboguttatus sp. nov.

14 ( 9 ) Body smaller, pronotum 1.1-1.2 times as broad as long. Basal margin of elytra not fringed with whitish scales. Third interval not curved inwards at base.

15(18) Elytra with a pair of large whitish patches behind middle from suture to fifth or seventh intervals.

16(17) Whitish patches on elytra containing one to three small fascicles on third and fifth intervals respectively, broadly contiguous to each other at suture and extending laterally to seventh intervals. Meso- and metasterna with concolorous scales. Mesepimera concolorous greyish brown to brown or a little darkened medianly. Scutellum round, convex. Length : 5.5-6.9 mm. Iriomote, Taiwan.

Colobodes formosanus Kôno

17(16) Whitish patches on elytra each subtriangular ranging from the posterior margin of second fascicle and anterior margin of third fascicle on third interval, to fourth fascicle on fifth interval, and with a internal branch oblique backwards from the anterior part to suture. Middle coxal cavities and mesepimera margined with grey. Scutellum flat, tongue-shaped, longer than broad. Length : 5.6-6.2 mm. Hokkaido, Honshu.

Colobodes matsumurai Kôno

18(15) Elytra at most with an indefinite greyish V-shaped small common patch between third intervals behind the middle.

19(20) Mesosternal process between middle coxae narrower than base of middle femur. Elytra with visible punctures in striae, each puncture with a narrow scale, without greyish V-shaped common patch behind middle. Fascicles on pronotum and elytra small, second and third fascicles on third interval circular. Length:5.5 mm. Iriomote. ..................................................

20(19) Mesosternal process between middle coxae broader than base of middle femur. Elytra with punctures in striae almost concealed by scales, often with a V-shaped indefinite small common patch between third intervals behind middle, with irregular small transverse blackish bands. Fascicles on pronotum and elytra larger, first and second fascicles on third interval oval, longer than broad. Length :6.0-7.6 mm. Hokkaido, Honshu, Shikoku, Kyushu.

Colobodes konoi Nakane

\section{KEY TO SPECIES BY THE MALE GENITALIA \\ (C.endai is not included)}

1(2) Penis very deeply and U-shapedly concave at apex. Colobodes matsumurai Kôno

2(1) Penis not or at most slightly notched at apex.

3(10) Penis broader than thick, weakly notched at apex. 
4(7) Internal sac with a pair of slender median sclerites.

5 (6) Penis robuster, main part of penis about 1.8 times as long as broad.

.......................... Colobodes formosanus Kôno

6( 5 ) Penis slenderer, about twice as long as broad. Colobodes kuniyoshii sp nov.

7 (4) Internal sac without sclerites.

8( 9 ) Main part of penis about 1.5 times as long as broad. Colobodes konoi Nakane

9( 8 ) Main part of penis about twice as long as broad. Colobodes ovipennis sp. nov.

10 ( 3 ) Penis truncate or produced apically.

11(12) Penis triangularly produced at apex, not setose at ostium, not swollen ventrad at apical third.

Colobodes valbum Roelofs

12(11) Penis subtruncate at apex, densely setose at ostium, more or less swollen ventrad at about apical third.

13(14) Lateral wall of penis broadly unsclerotized. Colobodes ornatoideus sp. nov.

14 (13) Penis evenly sclerotized at sides.

15(16) Penis cylindrical, more than twice as long as broad. Colobodes rotundicollis sp. nov.

16(15) Penis broader than thick, less than 1.7 times as long as broad.

17(18) Penis a little robuster, main part almost 1.5 times as long as broad.

Colobodes alboguttatus sp. nov.

18(17) Panis a little slenderer, main part about 1.7 times as long as broad. .....................

Colobodes ornatus Roelofs

\section{Colobodes ovipennis sp. nov.}

(Fig. 1)

Male : Derm dark brown, tibiae, tarsi and antennae reddish brown ; scaling predominantly greyish brown, pronotum with a greyish median stripe and a pair of dark areas, elytra with a common blackish subtriangular median patch ranging from exterior margins of median fascicles on third intervals to just behind the bases of second intervals via inner margins of subbasal fascicles on third intervals, posterior margin of the patch margined with a paler band ; lateral margins of thorax dark brownish, prosternum behind fore coxae and inside of pectoral canal with yellowish grey scales, prostemellum bare, the rest underside and coxae with greyish brown to yellowish grey scales.

Head with dense dark brown scales, rugulose, forehead between eyes as broad as the base of rostrum, with a fine median fovea, which usually concealed by scales. Rostrum evenly curved, median and two pairs of lateral carinae observable at middle, which becoming weaker basally and usually concealed by scales, apical area before antenna1 sockets bare, punctate. Antennae inserted into apical third of rostrum, first segment of funicle slightly longer than second, three distal segments of funicle globular, becoming wider distally, club nearly twice as long as broad, broadest before the middle.

Prothorax broader than long (11:10), parallel-sided on basal half, subapical constriction weak ; dorsum with oblong-oval scales forming a pair of fascicles at anterior margin and two pairs of fascicles across the middle, of which the median ones larger and each comprising 17-20 scales, lateral ones small and each comprising 4-5 scales. Scutellum as long as broad, bare, weakly convex.

Elytra oval, 4/5 times as broad as long, humeri oblique, humeral calli on the level of subbasal fascicles, third interval with three and fourth interval with four fascicles on nodes, third interval with subbasal fascicle brownish grey, oval, median fascicle blackish, much longer than broad, third fascicle small, greyish brown, fourth interval with subbasal fascicle larger than second and nearly as large as third and fourth, seventh interval convex, with 5-6 much smaller fascicles or pustulae, each comprises 


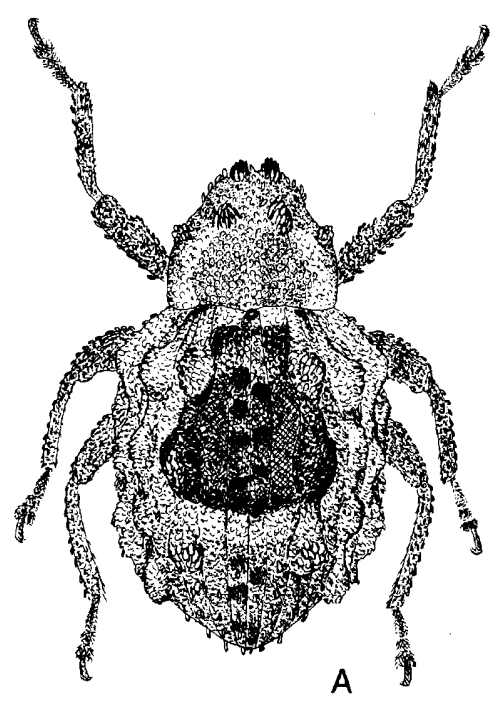

A
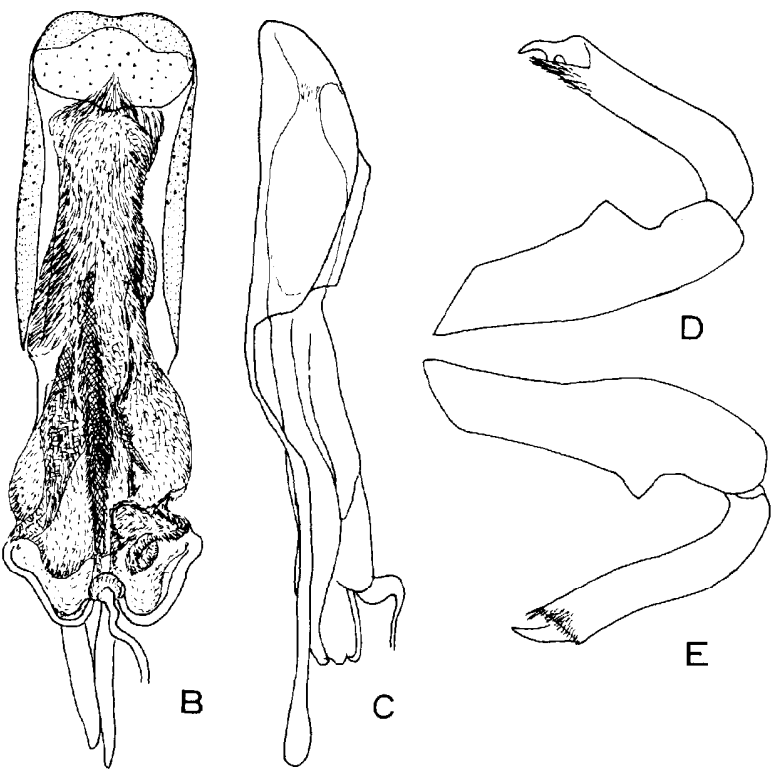

C

E

Fig. 1. Colobodes ovipennis sp. nov. A : Holotype. B, C : Penis, dorsal and lateral aspects. D : Fore leg. E: Hind leg.

a suberect broad scale.

Prosternum between fore coxae $1 / 3$ times the width of mesosternal process. Mesosternal process between middle coxae with_ small scales, a little wider than base of middle femur, not suddenly inflected, but continuously sloping in curve basally, and continued to metasternal process in weak slope. Metasternum between middle and hind coxae slightly longer than third ventrite. Venter with abdominal process 0.8 times as broad as hind coxa, first ventrite behind coxa as long as second. Fore and middle femora slightly, and hind femora distinctly clavate, dentate, without any definite scaly rings. Tibiae of the same width throughout, curved at base, then fore tibiae slightly bisinuate internally, and posterior four tibiae almost straight to apex. Third segment of tarsi shallowly concave at apical margins.

Female : Antennae inserted just before the middle of rostrum, rostrum scaled at basal area, with a weak median carina on basal third, lateral sides above scrobes with three rows of rough punctures on each side, apical half with distant fine punctures.

Length 4.7-5.2 $\mathrm{mm}$.

HolotyPe ơ (Type No. 2628, Kyushu Univ.), Mt. Shiratori, Kumamoto Pref., 7, vii. 1983, S. Imasaka leg.

PARATYPeS : Same locality as holotype, 19, 24. vi. 1982, S. Imasaka leg. ; lb, 14. v. 1983, M. Chûjô leg. Mt Hiko, Fukuoka Pref., 19, 1. vi. 1958, N. Gyotoku leg.

Distribution : Japan (Kyushu).

This is an aberrant member of the genus, and easily recognized by the oval elytra and the atrophied hind wings. 


\section{Colobodes endai sp. nov.}

(Figs, 2, 10C,11B)

Female : Derm dark reddish brown, prothorax blackish brown; scaling nearly concolorous greyish brown.

Head with vertex bare, shiny, punctate, forehead depressed and rugose, weakly depressed transversely between eyes and without median fovea. Rostrum densely scaled on basal half, with a median and a pair of lateral carinae behind the antennal sockets, which becoming weaker and entirely concealed by scales at base, apical half bare, punctate. Antennae inserted at apical third of rostrum, first segment of funicle $4 / 3$ times as long as second, third to seventh segments transverse, becoming wider distally, club 1.8 times as long as broad, broadest before the middle.

Prothorax broader than long (11:10), broadest at the middle, then very slightly and straightly narrowed posteriorly, rapidly narrowed anteriorly to weak subapical constriction ; dorsum reticulately punctate, with a median carina before the middle, anterior fascicles indefinite, with several suberect loose scales, median four fascicles on weak swellings also inconspicuous, each comprising several suberect loose scales. Scutellum subcordiform, as long as broad, shiny, weakly convex.

Elytra about 1.4 times as long as broad, parallel-sided to the middle, third, fifth and seventh intervals weakly costate at base ; third interval with 5-6 scaly fascicles, subbasal fascicle longer than broad, with 7-10 scales, second and third fascicles small, each with a few scales, median fascicle with 6-8 scales, postmedian fascicle larger than the former, as long as broad, with about 10 dense scales,

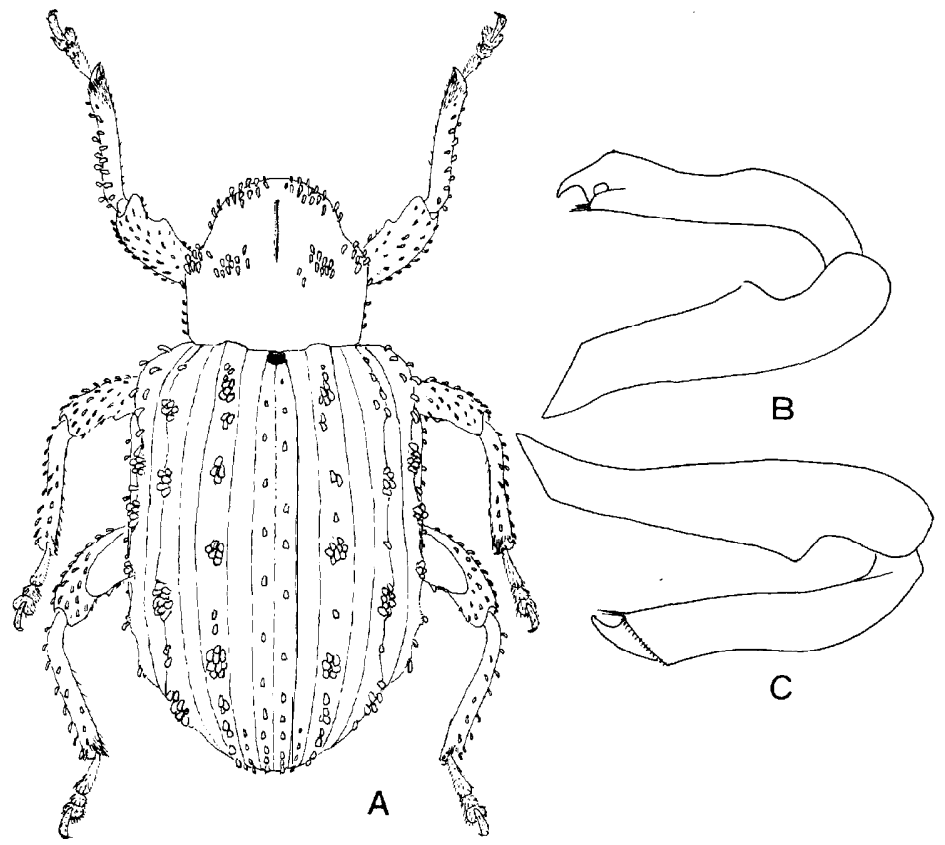

Fig. 2. Colobodes endai sp. nov. A : Holotype. B : Fore leg. C : Hind leg. 
subapical fascicle on declivity small, with a few scales ; fifth interval with four fascicles, subbasal fascicle with a few scales, second fascicle with 5-6 scales, third fascicle behind the middle larger than the second, with 7-9 scales, fourth fascicle on subapical callus longer than broad, with 6-8 scales; seventh interval with six small fascicles or pustulae comprising 1-5 scales each ; first interval in entire length and second interval near apex each with a row of suberect scales.

Prosternum between coxae $2 / 5$ times the width of mesostemal process, the latter distinctly narrower than base of middle femur. Metasternum between middle and hind coxae as long as first ventrite behind coxa. Abdominal process $2 / 3$ times the width of hind coxa. Venter thinly punctate, interstices between punctures nearly as broad as their diameters, a little denser at sides and posterior margin, each puncture with a narrow small scale, first ventrite behind coxa as long as second. Femora clavate. Tibiae with outer margin sinuate. Third tarsal segment deeply notched.

Male : Unknown.

Length : $5.0-6.2 \mathrm{~mm}$.

Holotype 9 (Type No. 2629, Kyushu Univ.), Asakawa, Hachioji, Tokyo, viii. 1961, N. Enda leg.

Paratype: Mt. Gomadan, Wakayama Pref., 19, 22. vii. 1979, I. Matoba leg.

Distribution: Japan (Honshu).

This new species is easily separable from the others by the concolorous scaling and spaced small scales on the venter. The holotype was captured by Mr. Nobuo Enda, a keen forest entomologist of the Forest and Forest Products Research Institute, on a dead pine log.

\section{Colobodes rotundicollis sp. nov.}

Male : Derm blackish, apices of tibiae, tarsi and antennae reddish brown; background scaling predominantly ash brown to dark ash brown, head dark brown, with a median and lateral greyish brown stripes, pronotum with an indefinite median stripe, elytra with second, fourth and sixth intervals black at bases, with a pair of blackish oblique bands combining second fascicles on third and fifth intervals, the band often extending internally to suture and externally to side margins as narrow dark streaks, odd intervals often with a few dark spots, often with a common greyish V-shaped patch behind the middle combining postmedian whitish fascicles on third intervals, underside predominantly brownish grey, often side pieces of meso- and metathoraces dark brown and a brownish indefinite patch at each side of ventral segments.

Head with vertex opaque, bare, punctate, forehead densely scaled, not demarcate with vertex by depression, with a median fovea between eyes, but almost concealed by scales. Rostrum robust, evenly curved, with a median and two pairs of lateral weak carinae on basal two-thirds, which obsolete and concealed by scales at base, with a row of small suberect scales on each interstices between carinae, weakly rugose between antennal sockets, then shiny and punctate to apex. Antennae with first segment of funicle as long as second, third segment as long as broad, fourth to seventh segments transverse, becoming wider distally, club nearly twice as long as broad, broadest at middle.

Prothorax 1.2 times as broad as long, broadest behind the middle, evenly rounded at sides from hind angles to subapical constriction, anterior fascicles with short dense scales, median four fascicles on weak swellings with suberect scales slightly larger than those of the anteriors, reticulate punctures almost concealed by scales. Scutellum small, as long as broad, weakly convex.

Elytra obovate, 4/3 times as long as broad, broadest at basal third, evenly convex dorsally, third, fifth and seventh intervals convex and greyish from subbasal fascicles to base, second fascicles on third and fifth intervals black, with 8-10 scales, third fascicles small, with 3-5 brownish scales, fourth fascicle on third interval behind the middle greyish to whitish, with 6-8 scales, fourth fascicle on fifth 

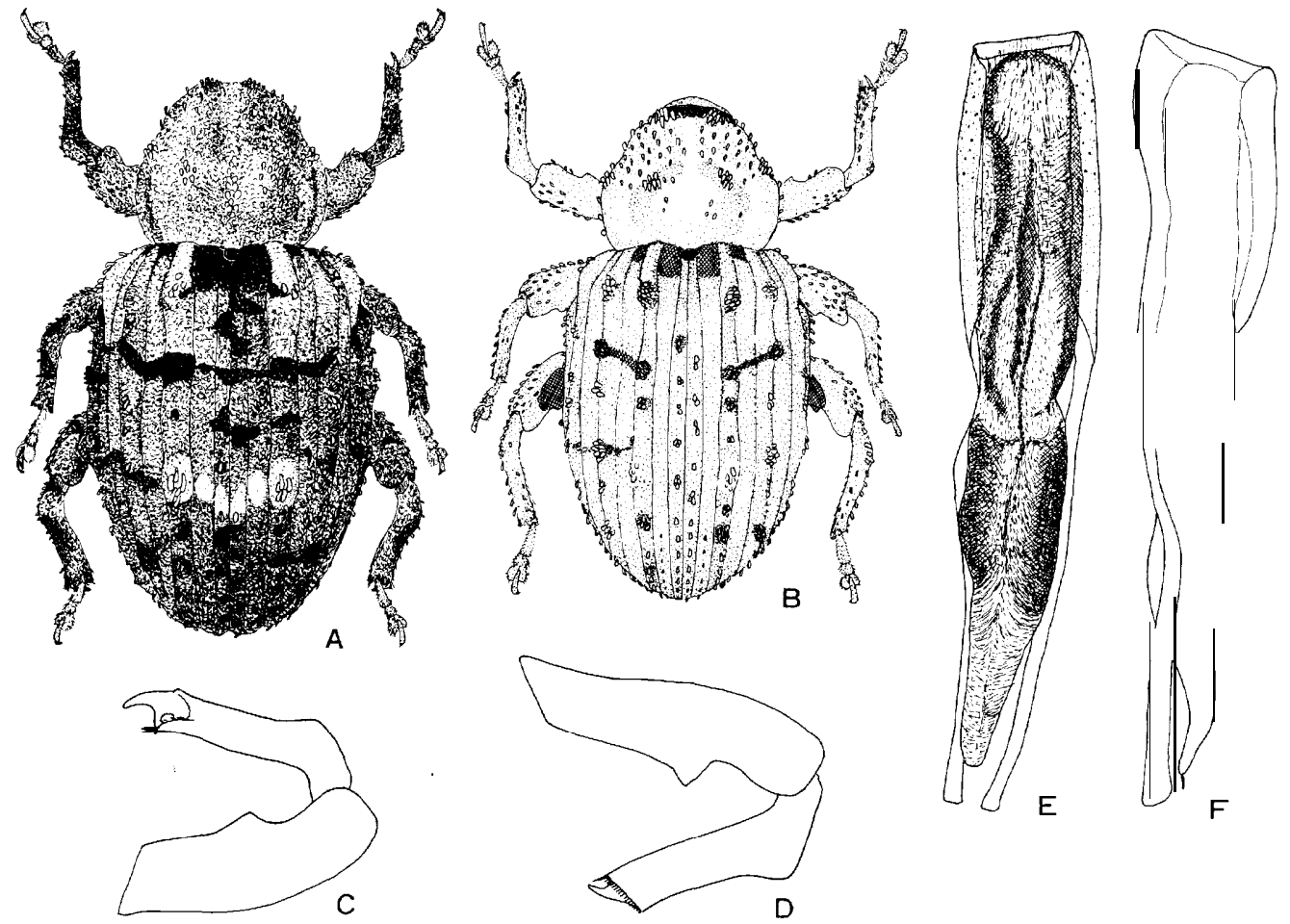

Fig. 3. Colobodes rotundicollis sp. nov. A : Paratype of normal form. B : Paratype of ash brown form. C : Fore leg. D: Hind leg. E, F: Penis, dorsal and lateral aspects

interval maller than that on third, brownish or often mixed with dark scales, one or two fascicles on declivity with a few dark brown scales on blackish spots, seventh interval with 5-8 small fascicles or pustulae comprising a few scales excepting humeral one.

Prosternal process between coxae narrow, $3 / 5$ times the width of mesosternal process, the latter slightly narrower than base of middle femur. Metastemum between middle and hind coxae $5 / 8$ times the length of'first ventrite behind coxa and a little longer than third ventrite. Metastemum and venter with two kinds of scales, one small and prostrate, the other suberect, a little larger and borne in punctures. Abdominal process $5 / 6$ the width of hind coxa, first ventrite behind coxa as long as second. Hind wings atrophied.

Fore femora robust, hardly clavate, middle and hind feniora clavate. Tibiae triangularly dilated externally near the base. Third tarsal segment deeply notched.

Female : Rostrum scaled near base, median carina obsolete, bare and punctate on apical twothirds, antennae inserted at apical third.

Length : 6.0-6.6 mm.

HolotyPE $\sigma^{\top}$ (Type No. 2630, Kyushu Univ.), Hungtou, Lan Hsu, Taitung Hs., Taiwan, 4-6. vi. 1980, H. Makihara leg.

PARATYPeS : Same data as holotype, $10^{\top} 19$. Hungyeh Wenchuan, Nanatou Hs., Taiwan, 16 19,1-

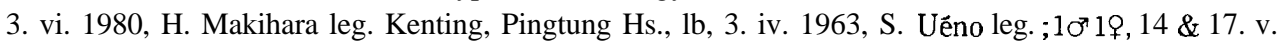


1978, T. Senoh leg. Lushan, Nantou Hs., Taiwan, 19, 20. vi. 1976, H. Makihara leg. Hui-Sun Exp. Forest, Taiwan, 19, 8. vi. 1978, K. Kusama leg. Lan Yu I., Taiwan, 10'1\%, 12 \& 14. viii. 1968, 'H. Makihara leg. Sonai, Iriomote I., 19, 6. x. 1963, K. Morimoto leg. Kabira, Ishigaki I., 10’', 31. iii. 1984, N. Nishida leg. Yoshihara, Ishigaki I., 19, 28. iii. 1975, H. Ohira leg.

Distribution : Japan (Ishigaki, Iriomote), Taiwan.

This new species is close to ornatoideus sp. nov. at first sight, but the pronotum and elyra are evenly rounded laterally and the tibiae are triangularly expanded near the base.

\section{Colobodes valbum Roelofs}

(Fig. 6A, B)

Colobodes v-album Roelofs, 1875, Ann. Soc. ent. Belg., XVIII : 155 (Japon). - Voss, 1958, Decheniana, Beihefte $5: 50$ (Fukien: Kuatun).

Colobodes valbum: Morimoto, 1984, Coleopt. Jap. in col., IV :335, Pl. 66, Fig. 2 (Kyushu).

Male : Derm blackish, apices of tibiae, tarsi, antennae and apical part of rostrum reddish brown ; scaling predominantly ash grey mixing brownish grey, with a median indefinite greyish stripe on pronotum and a common V-shaped greyish patch on elytra behind the middle, head with median and lateral greyish stripes.

Head and basal two-thirds of rostrum densely scaled, forehead between eyes greyish, with a weak median depression and a pair of small hair tufts between eyes. Rostrum with surface structures completely concealed by scales on basal two-thirds, then bare and punctate to apex. Antennae inserted at apical fourth, distance between apex and antennal socket shorter than apical width, first segment of funicle robust, as long as second, third segment as long as wide, the remaining segments transverse and successively wider distally, club 1.7 times as long as broad.

Prothorax transverse $(7: 6)$, broadest at the base, very weakly and straightly narrowed to the middle, then rapidly narrowing to subapical constriction, fascicles rather conspicuous. Scutellum subcordiform, a little longer than broad, shiny, weakly convex.

Elytra 1.5-1.6 times as long as broad, parallel-sided to the middle, third interval convex from subbasal fascicle to base, second fascicle median, with 16-20 brownish scales and marginate anteriorly with blackish prostrate scales, third fascicle behind the middle brownish grey, with greyish margin, fifth interval with 3-4 small fascicles between subbasal and subapical fascicles, each with a few small scales, seventh and ninth intervals each with small fascicles or pustulae.

Prosternal process between coxae as broad as to a little narrower than mesosternal process, which much narrower than base of middle femur. Metasternum between middle and hind coxae about 0.6 times as long as first ventrite behind coxa. Abdominal process 0.7 times as wide as hind coxa. First ventrite behind coxa a little longer than second.

Femora weakly clavate. Tibiae triangularly expanded near the base as in rotundicollis.

Female : Distance between apex of rostrum and antennal socket as long as the apical width of rostrum.

Length : 5.5-6.2 mm.

Specimens eXamined : Tabarushita, Okayama Pref., 10̛, 25. iv. 1976, S. Naomi leg. Mt. Joyama, Fukuoka Pref., 10' 16. v. 1974, K. Kido leg. Mt. Fukuchi, Fukuoka Pref., 19, 5. v. 1954, T. Yoshida leg. Mt. Inunaki, Fukuoka Pref., 10'19, 5. v. 1954, C. Okuma \& K. Morimoto leg. Mt. Homan, Fukuoka Pref., 19, 15. v. 1975, H. Irie leg.

Distribution : Japan (Honshu, Kyushu), China (Fukien).

The type is in the British Museum (Natural History) and examined. 


\section{Colobodes ornatoideus sp. nov.}

(Fig. 4)

Male : Derm blackish, apices of tibiae, tarsi and antennae reddish brown ; scaling of head small, dense, black, pronotum with oval scales mixing grey and brown, with indefinite greyish median and lateral stripes, posterior margin of pronotum marginate with yellowish white small scales, elytra fringed along basal margin with whitish small scales, with basal area broadly greyish to brownish grey between humeri and exterior half of third intervals, bases of first and second intervals and interior half of third interval from base to subbasal fascicle black, bases of fourth and often sixth intervals narrowly blackish, with a blackish oblique fascia from lower part of humeral callus to median fascicle on third interval, often with another black fascia from side margin a little before hind coxa to the exterior base of postmedian fascicle on fifth interval, and also with irregular narrow short bands on declivity, lateral pieces of meso- and metathoraces much darker than sterna.

Head with vertex rugose, demarcate from forehead by depression, forehead between eyes with a median depression and a pair of brownish small area at sides. Rostrum with weak five carinae on basal half, being obsolete and concealed by scales at base, each interstices between carinae with a row of oval small suberect scales besides small prostrate scales, bare and punctate on apical third. Antennae with basal two segments of funicle equal in length, third segment as long as broad, fourth to seventh segments globular, a little broader than long, successively wider distally, club about 1.5 times as long as broad, broadest at apical third.

Prothorax 1.25-1.30 times as broad as long, broadest at basal third, weakly curved laterally,
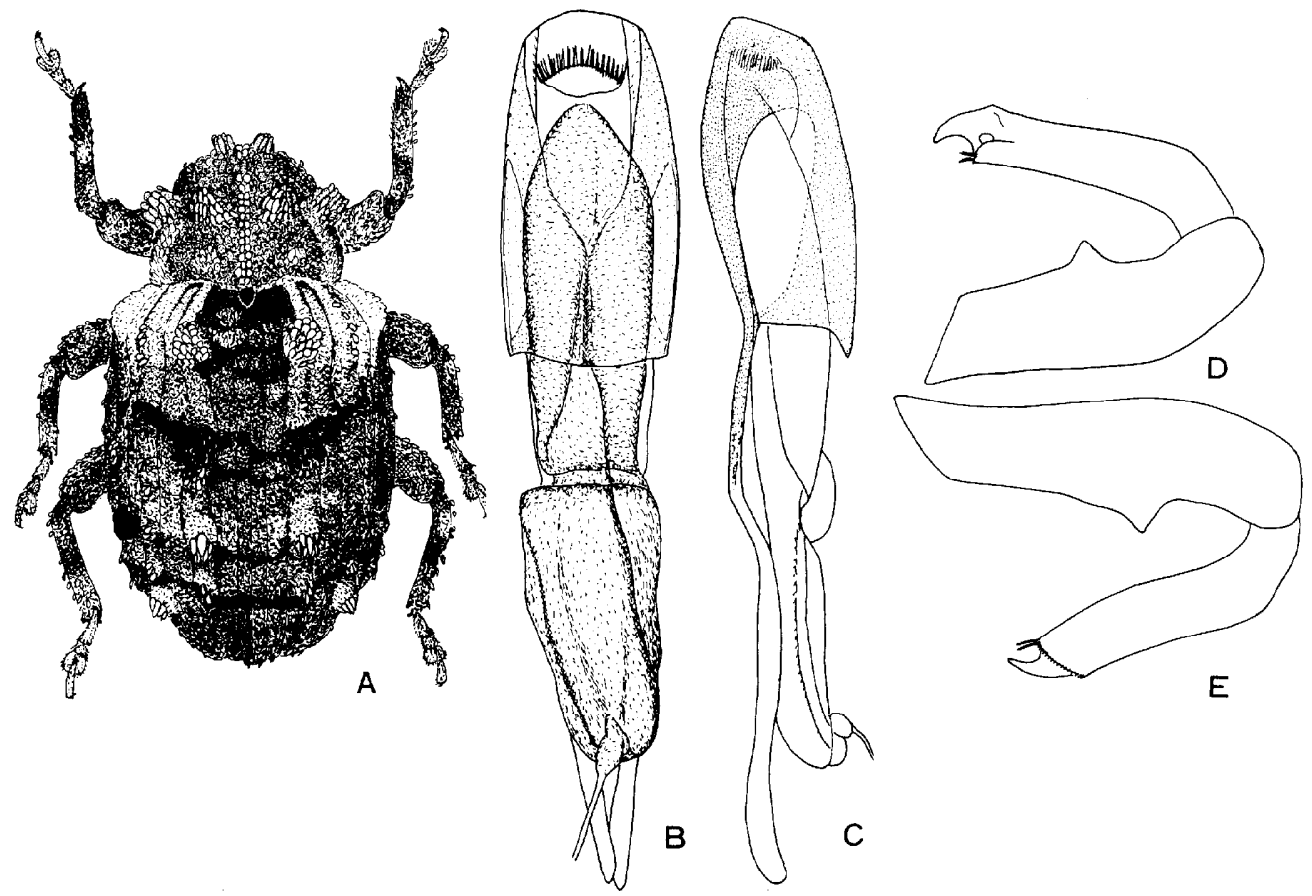

Fig. 4. Colobodes ornatoideus sp. nov. A : Holotype. B, C: Penis, dorsal and lateral aspects. D : Fore leg. E : Hind leg. 
fascicles conspicuous, anterior fascicles smaller than the median ones. Scutellum subcordicorm, a little longer than broad, anterior part convex and shiny, posterior part flat and opaque.

Elytra 1.3 times as long as broad, parallel-sided on basal half, third to sixth intervals curved inwards from subbasal fascicles to the bases, third interval with subbasal fascicle greyish brown, with dark brown to blackish scales on the inner margin, second fascicle just before the middle blackish, third fascicle behind the middle whitish to greyish brown, fourth fascicle on declivity small and black, fifth interval with subbasal and subapical fascicles of medium size, with 4-5 small fascicles between them, fascicles or pustulae on seventh and ninth intervals indistinct, each comprising only one or two suberect small scales.

Prosternal process between coxae $3 / 5$ to $1 / 3$ times the width of mesosternal process, the latter a little broader than base of middle femur, but $2 / 3$ the width of middle coxa. Metastemum between middle and hind coxae a little shorter than first ventrite behind coxa. Abdominal process 0.7 times the width of hind coxa, first ventrite behind coxa as long as second.

Fore femora slightly clavate, posterior four femora distinctly clavate. Tibiae slightly broader at curved basal area than the anterior part. Third tarsal segment deeply notched.

Female : Rostrum bare, shiny and punctate on apical half, distance between antennal socket and apex 1.2 times the width of apex.

Holotype ơ (Type No. 2631, Kyushu Univ.), Nakanoshima I., Tokara Isls., 25-30. iv. 1975, H. Irie leg.

Paratypes : Same data as holotype, $4 \sigma^{\top} 6$. Same locality as holotype, $1 \sigma^{\top 3} 39$, 1-2. v. 1975, H. Irie

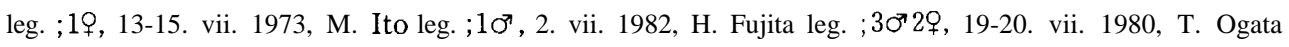
leg. ; lb, 19. vii. 1984, Y. Takai leg. ;10’, 19. vii. 1986, T. Ogata leg. ;1073\%, 30. iv. 1987, T. Ogata leg. Akuseki-jima I., Tokara Isls., 207, 30. vii. 1969, M. Sakai leg. Kuchinoshima I., Tokara Isls., 20 39, 26. vi. 1969, H. Makihara leg. Mt. Yui, Amami-Oshima, 19, 21. vii. 1980, N. Yamamoto leg. Nishinakama, Amami-Oshima, 10̛, 24. v. 1978, H. Makihara leg. Mikyo, Tokunoshima, 16, 27. vii. 1963, Y. Hirashima leg. Kunigami, Okinawa, 19, 7. vi. 1977, H. Irie leg. Nakanogo, Hachijo I., 1우, 8. vii. 1981, Y. Kusakabe leg.

Distribution : Japan (Hachijo, Akuseki, Kuchinoshima, Amami-Oshima, Tokunoshima, Okinawa).

This is close to C. ornatus Roelofs, but the basal part of elytra is broadly greyish to brownish grey, the whitish spot on postmedian fascicle of the third interval is much smaller, and the penis is broadly unsclerotized at sides.

\section{Colobodes ornatus Roelofs}

(Fig. 6C, D)

Colobodes ornatus Roelofs, 1875, Ann. Soc. ent. Belg., XVIII : 156 (Japon). -Nakane, 1963, Icon. Ins. Jap. col. nat. ed., II : 370, Pl. 185, Fig. 14 (Kyushu). -Morimoto, 1984, Coleopt. Jap. in col., IV : 335, P1. 66, Fig. 3 (Honshu, Kyushu).

Very close to C. ornatoideus sp. nov. Scaling predominantly blackish on pronotum with greyish median stripe and basal fringe, elytra with short basal greyish stripe on third interval before subbasal fascicle, postmedian fascicle on third interval conspicuous, whitish, and much larger than median black fascicle.

M ale : Rostrum with a median and two pairs of lateral sharp carinae, distance between apex and antenna1 socket slightly longer than apical width. Prosternal process between coxae 0.41-0.52 times as broad as mesostemal process, the latter much narrower than base of middle femur. Metasternum between middle and hind coxae $5 / 7$ times the length of first ventrite behind coxa. Tibiae distinctly 
angulate at basal third. Third tarsal segment triangularly notched at apex.

Female : Rostrum before antennal socket 1.2-1.3 times as long as apical width.

Length : 6.0-7.8 $\mathrm{mm}$.

Specimens examined: 12 specimens from Kanagawa (Mt. Takatori), Tochigi (Nikko), Kyoto (Kamo), Fukuoka (Mt. Hiko, Mt. Wakasugi), Oita (Kuju) and Kagoshima (Cape Sata) Prefs., Tsushima I. and Yakushima I.

Distribution : Japan (Honshu, Kyushu, Tsushima, Yakushima).

The type is in the British Museum (Natural History) and examined.

\section{Colobodes alboguttatus sp. nov.}

(Figs. 5, 10C)

M ale : Derm blackish, apices of tibiae, tarsi, antennae and apex of rostrum reddish brown ; background scaling variegated with dark brown and greyish brown, pronotum with a greyish median stripe and basal fringe, elytra with greyish short stripes on third, fifth and humeral intervals at bases before subbasal fascicles and greyish basal fringe, second, fourth and sixth intervals blackish at bases, third interval with subbasal fascicle brownish, with blackish internal margin, second fascicle median, dark brown, with black base, third fascicle behind the middle the largest, oval, whitish, fourth fascicle on declivity small, with a few dark brown scales and blackish base, fifth, seventh and ninth intervals each with 6-7 small fascicles or pustulae, each of which with a few or one dark scales, meso- and metasterna and first ventrite behind coxa brownish grey to grey, lateral pieces of mesothorax almost brownish, metepisterna brownish with greyish median part, venter brownish at sides,

Head with vertex roughly punctate, weakly demarcated from forehead by depression, forehead almost concealed by brown scales, with a median depression between eyes. Rostrum with a sharp median and two pairs of weak lateral carinae behind the antennal insertion, with a row of short suberect scales in each interstice between carinae on basal area, with a shallow short median sulcus between antennal sockets, apical area punctate, distance between apex and antennal socket 1.2 times the apical width. Antennae with second segment of funicle slightly longer than first, third segment a little longer than broad, fourth segment as long as broad, fifth to seventh segments transverse, club slender, 2.2 times as long as broad, broadest at apical third.

Prothorax 1.2 times as broad as long, parallel-sided on basal half, anterior fascicles black, with 7-8 scales, median fascicles much larger than the anteriors, with greyish scales at rear and blackish ones in front, lateral fascicles small, compact, with several dark brown scales. Scutellum obovate, a little longer than broad, convex, bare.

Elytra about 1.4 times as long as broad, parallel-sided on basal half, third to sixth intervals curved inwards to the base before subbasal fascicles.

Prosternal process between coxae about 0.4 times as broad as mesosternal process, the latter distinctly narrower than base of middle femur. Metasternum between middle and hind coxae $5 / 7$ times the length of first ventrite behind coxa. Ventral process $2 / 3$ times the width of hind coxa, first and second ventrites with dense prostrate scales and distant larger scales borne in punctures, the prostrate ones almost absent at the median part behind the middle in first ventrite.

Fore femora slightly clavate, middle and hind femora clavate. Tibiae weakly dilated externally at apices. Third segment of tarsi broad-triangularly emarginate at apex.

Female : Only separable from the male by the slightly slenderer rostrum, distance between apex and antennal socket 1.3-1.4 times as long as apical width.

Length : 6.8-8.3 mm.

Holotype $q$ (Type No. 2632, Kyushu Univ.), Mt. Omotodake, Ishigaki I., 18-21. iv. 1975, H. Irie 


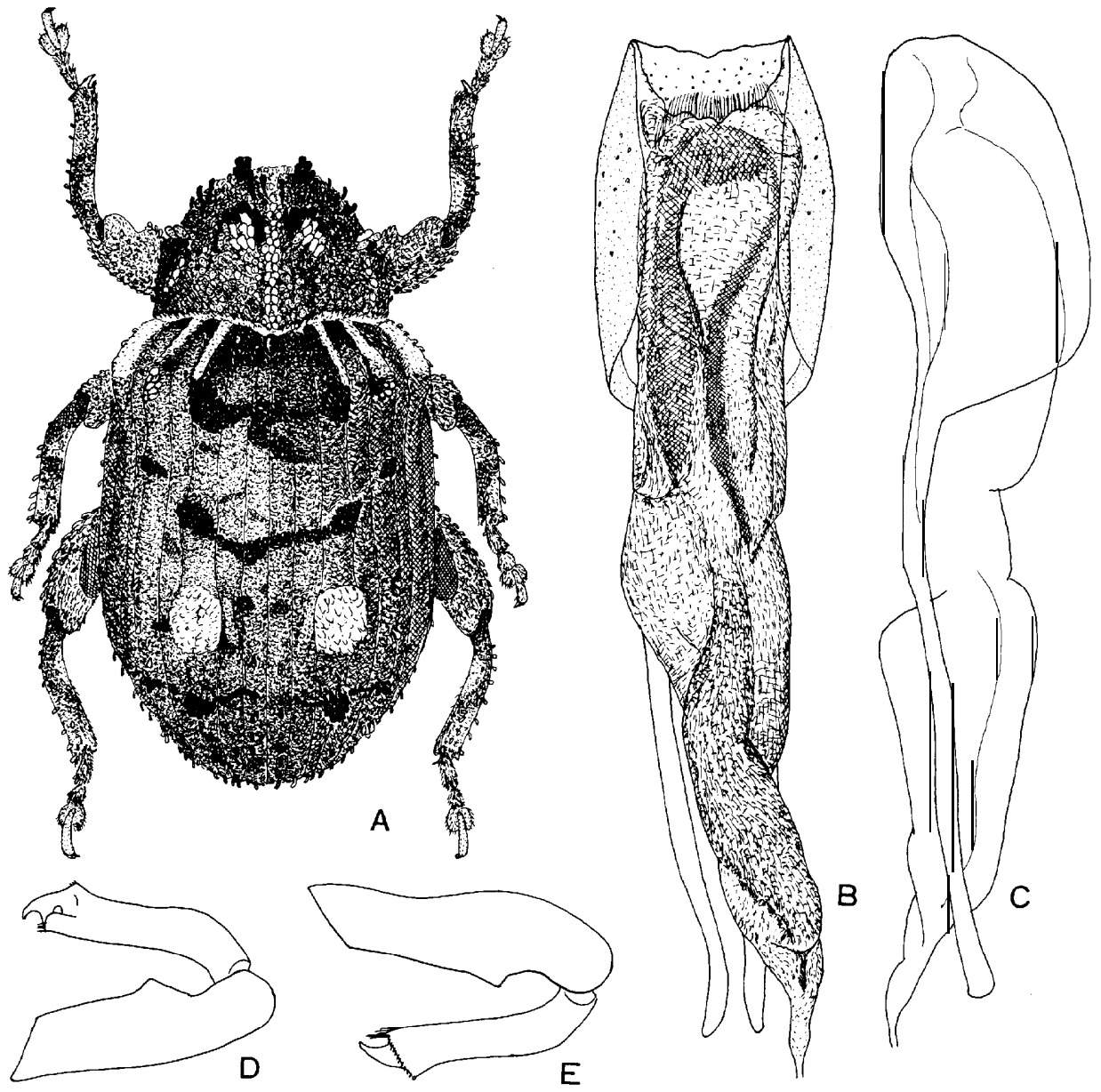

Fig. 5. Colobodes alboguttatus sp. nov. A: Holotype. B, C: Penis, dorsal and lateral aspects. D : Fore leg. E: Hind leg.

leg.

PARATYPES: Same locality as holotype, 1q, 17. ii. 1974, S. Imasaka leg. ;1 $\sigma^{\top} 1$, 1-2. iv. 1974, H. Ohira leg. ; 19, 8-11. iv. 1975, H. Irie leg. ;1 9,25 . v. 1978, N. Morishima leg. Mt. Bannadake, Ishigaki, 1ㅇ, 14. vi. 1975, N. Kanie leg. Sonai, Iriomote, 1, 6. x. 1963, K. Morimoto leg.

DistRIBUTION : Japan (Ishigaki and Iriomote Isls.).

This new species is similar to C. ornatus Roelofs and ornatoideus sp. nov., but a pair of fascicles on the third intervals behind the middle are conspicuous, the fascicles on the fifth and seventh intervals are much smaller, and blackish small patches or fasciae are less pronounced on the elytra.

\section{Colobodes formosanus Kôno}

(Figs. 7A, B, 10A, B)

Colobodes formosanus Kôno, 1932, Ins. Mats., VI : 180, Taf. VI, Fig. 7 (Taiwan: Koshun, ).- 
Morimoto, 1963, Rep. Commit. Foreign Sci. Res., Kyushu Univ., (1) : 111, pl. II, Fig. G (Ishigaki). -Morimoto, 1984, Coleopt. Jap. in col., IV : 335, PI. 66, Fig. 1 (Taiwan, Iriomote).

This species is easily recognized by the whitish broad patches on the elytra behind the middle as noted in the key and the figures by Morimoto $(1963,84)$.

Prosternal process between coxae about 0.3-0.4 times the width of mesosternal process, the latter much narrower than base of middle femur. Metasternum between middle and hind coxae $5 / 7$ times as long as first ventrite behind coxa.

SPecimens eXAmined : 12 specimens from Ishigaki (Mt. Kaarayama), Iriomote (Shirahama, Mokutan), Taiwan (Hui Sun Exp. Forest, Kenting Park, Nanshanchi, Chiao-Li-Ping, Suleng).

Distribution : Japan (Ishigaki, Iriomote), Taiwan.

\section{Colobodes matsumurai Kôno}

(Fig. 6E, F)

Colobodes matsumurai Kôno, 1932, Ins. Mats., VI : 179, Taf. VI, Fig. 6 (Sapporo, ợ). -Nakane, 1963, Icon. Ins. Jap. col. nat. ed., II : 369, pl. 185, Fig. 12 (Hokkaido). -Morimoto, 1984, Coleopt. Jap. in col., IV : 332, pl. 65, Fig. 28 (Hokkaido, Honshu; host-tree :Ulmus davidiana). Another characteristic species by the whitish patches can be identified easily by the colour figures
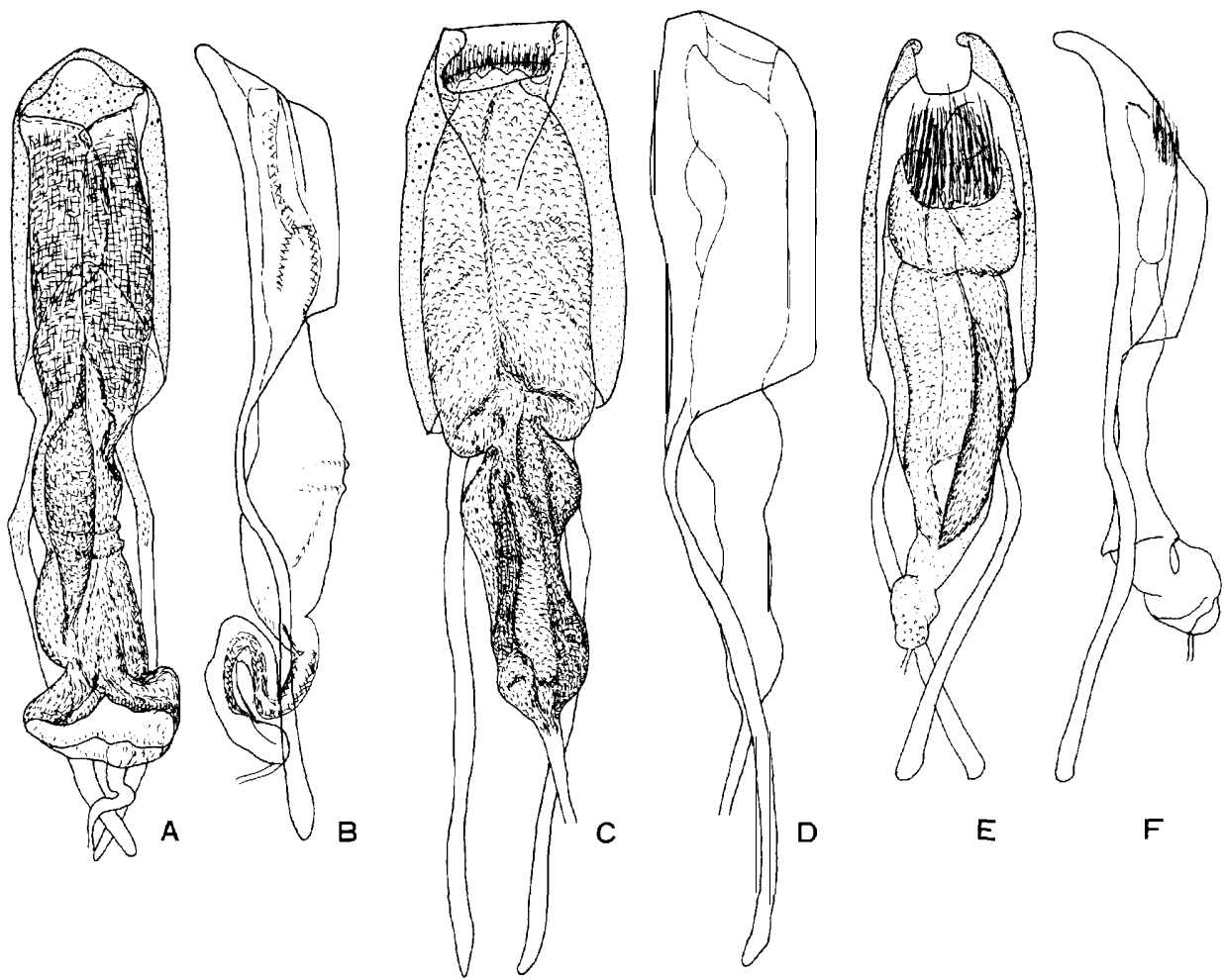

Fig. 6. Penis of Colobodes spp., dorsal and lateral aspects. A, B : C. valbum Roelofs. C, D : C. ornatus Roelofs. E, F : C. matsumurai Kôno. 
in the above mentioned literatures.

Prosternal process between coxae narrow, $1 / 3-1 / 4$ times the width of mesostemal process, the latter about as broad as base of middle femur. Metasternum between middle and hind coxae $5 / 6$ times the length of first ventrite behind coxa. Abdominal process $3 / 4$ times as broad as hind coxa.

SPecimens eXAmined : 21 specimens from Hokkaido (Sapporo, Kamiotoineppu, Antaroma), Fukushima (Yunohana spa.), Gunma (Mt. Hotaka, Kita-Karuizawa), Tochigi (Chuzenji, Nikko), Nagano (Todai), Gifu (Hirayu), and Oita (Mt. Kurodake) Prefs., Korea (Gang Weon Do).

Distribution : Japan (Hokkaido, Honshu, Kyushu), Korea.

BIOLOGY : Larvae, pupae and immature adults were captured on the underside of bark of dead Ulmus davidiana var. japonica on July 26, 1959, at Ashoro, Hokkaido.

\section{Colobodes konoi Nakane}

(Figs. $7 \mathrm{C}-\mathrm{F}, 8,11 \mathrm{~A}$ )

Colobodes konoi Nakane, 1963, Fragm. Coleopt., (9) : 37 (type : Kamikochi ; Shimashimadani, OkuNikko, Sounkyou, Nukabira). -Nakane, 1963, Icon. Ins. Jap. col. nat. ed., II : 369, pl. 185, Fig. 13 (Honshu). -Morimoto, 1984, Coleopt. Jap. in col., IV : 332, pl. 65, Fig. 27 (Hokkaido, Honshu, Shikoku, Kyushu ; host-trees : Fraxinus spaethiana, Pterocarya rhoifolia).

Colobodes v-album : Kôno(nec Roelofs), 1936, Trans. biogeogr. Soc. Jap., 1: 100 (Mt. Daisetsu ; on stem of Tilia japonica).

Male : Background scaling dark brown to brownish black, pronotum with greyish brown median stripe and lateral patches, anterior fascicles with brownish to dark brownish scales mixing some darker ones anteriorly, median two fascicles brownish to dark brown, lateral fascicles small, with a
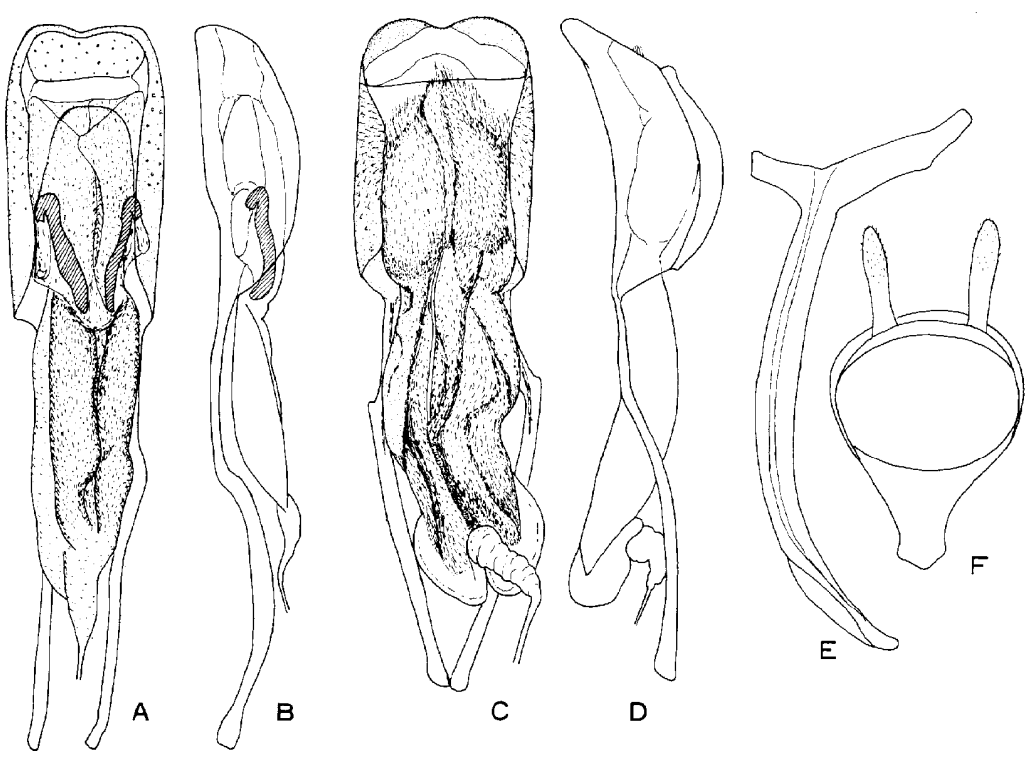

Fig. 7. Male genitalia of Colobodes spp. A, B : C. formosanus Kôno, penis. C-F: C. konoi Nakane (C, D : Penis, E : 9th stemite, F : Tegmen). 
few dark scales, elytra always blackish at the bases of fourth and fifth intervals, often blackish at the base of second interval, third interval with subbasal fascicle brownish or anterior part brownish and posterior part blackish, second fascicle before the middle blackish, third fascicle behind the middle small, with a few dark brown to blackish scales, fifth interval with subbasal fascicle brownish, much smaller than those on third interval, subapical calli blackish, with two small blackish fascicles between them, often with one additional fascicle before subapical callus, underside with greyish to brownish grey scales, mesepimera and metepisterna often dark brown to brown.

Distance between antennal socket and apex of rostrum 1.5 times the apical width. Antennae inserted just before the middle of rostrum, with second segment of funicle a little longer than first, club twice as long as broad. Prostemal process between coxae about $1 / 3$ times the width of mesostemal process, the latter a little broader than base of middle femur. Metastemum between middle and hind coxae a little shorter than first ventrite behind coxa. Abdominal process $5 / 6$ times the width of hind coxa.

Female : Antennae inserted in the middle of rostrum, distance between antennal socket and apex twice the apical width.

Length : 6.0-7.6 mm.

SPECIMENS EXAMINED : 37 specimens from Hokkaido (Engaru, Senpoku-toge, Mt. Tottanbetsu, Yubari, Mt. Tarumae), Aomori (Shimokita), Fukushima (Hinoemata, Yunohana spa.), Gunma (Sugenuma), Niigata (Mt. Washigazu), Tochigi (Yumoto, Kuriyama), Yamanashi (Fuji-rindo, Mt. Daibosatsu, Mt. Kitadake), Nagano (Mt. Ontake), Shizuoka (Misakubo), Kochi (Makiyama), Ehime (Mt. Ishizuchi), Fukuoka (Mt. Hiko), Oita (Mt. Kuju).

Distribution : Japan (Hokkaido, Honshu, Shikoku, Kyushu).

Biology : Larvae feed on the cambium of dead trees, Fraxinus spaethiana, Pterocaryarhoifolia, etc.

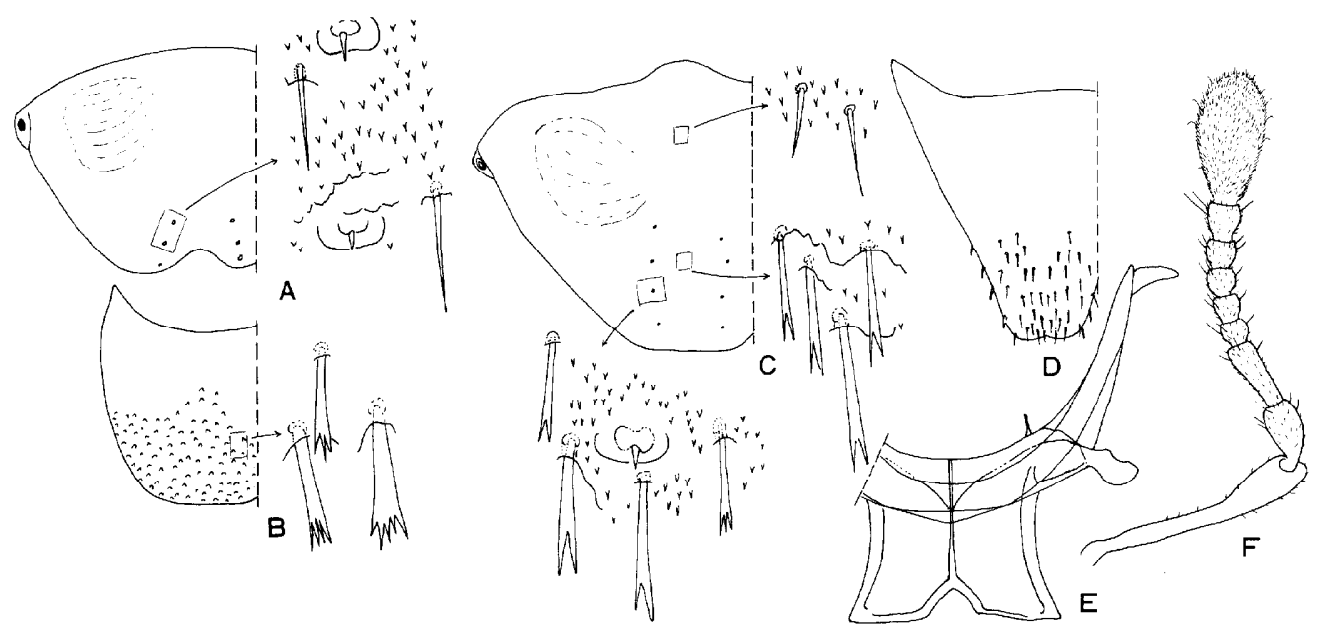

Fig. 8. Colobodes konoi Nakane. A : Male 7th tergite. B : Male 8th tergite (pygidium). C : Female 7th tergite (pygidium). D : Female 8th tergite. E : Metendostemite. F : Antenna. (Tergites partly enlarged to show setae and scrapers). 


\section{Colobodes kuniyoshii sp. nov.}

(Fig. 9)

General appearance very similar to C. endai sp. nov.

Male : Derm dark reddish brown, with reddish brown apices of tibiae, tarsi, antennae and apex of rostrum, prothorax much darker ; scaling predominantly dark brownish.

Head with vertex separately punctate, bare, demarcated from forehead by depression, forehead with a pair of dark patches, with a shallow median depression and a pair of pale scaly tufts between eyes. Rostrum scaled on basal half, with a median and two pairs of lateral carinae behind antennal sockets, outer carinae weak, all carinae weakened at base and completely concealed by scales, each interval between carinae with a row of distant small scales, apical area punctate, distance between apex and antennal socket almost as long as apical width. Antennae inserted in the apical third of rostrum, first segment of funicle as long as second, third segment as long as broad, the rest slightly broader than long and successively broader distally, club twice as long as broad, broadest at apical third.

Prothorax weakly rounded from base to shallow subapical constriction, broadest at the middle, disc with oval prostrate scales, with a median and lateral indefinite greyish stripes, anterior fascicles with dense scales, median fascicles much larger than the anteriors, lateral fascicles small, with several scales, these fascicles brownish. Scutellum as long as broad, convex.

Elytra 1.4 times as long as broad, parallel-sided on basal half, third interval with subbasal fascicle brownish, as large as second fascicle at basal third, third to fifth fascicles much smaller, each with a few scales, second to fifth fascicles with dark scales and blackish to dark brown bases, fifth interval

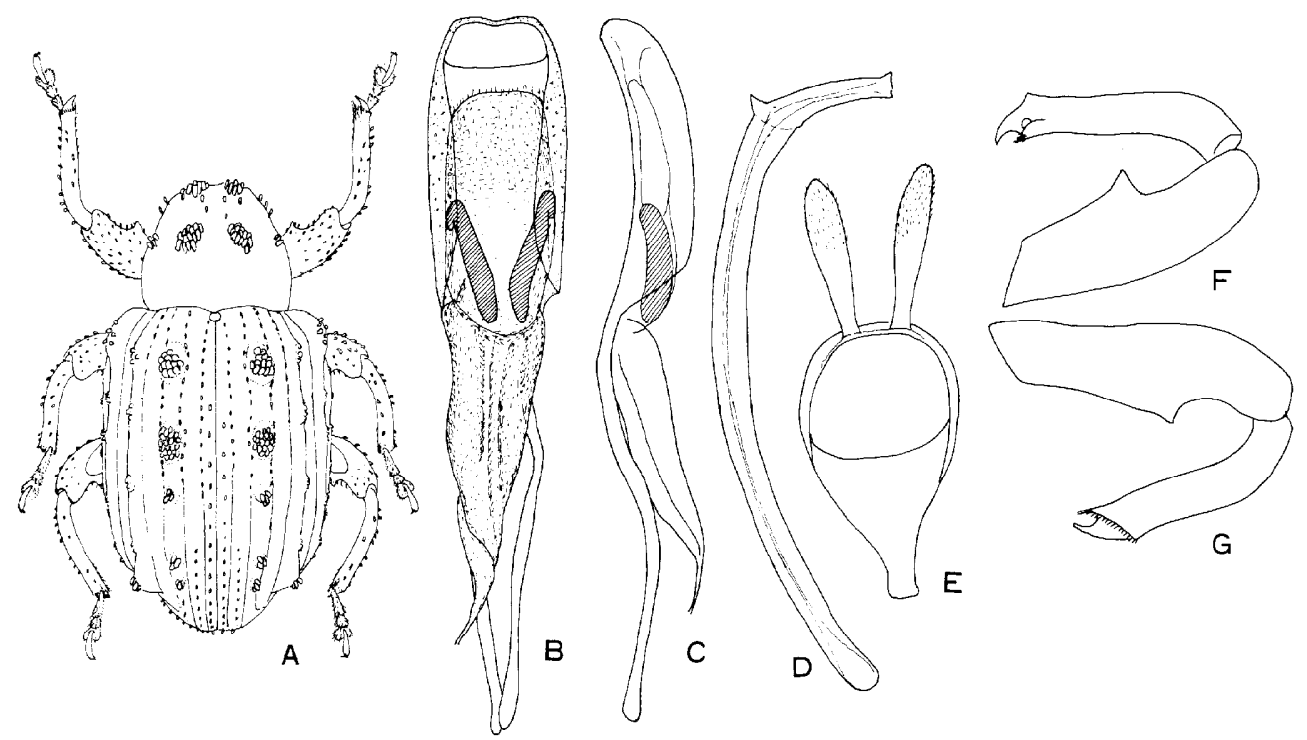

Fig. 9. Colobodes kuniyoshii sp. nov. A : Holotype. B, C: Penis, dorsal and lateral aspects. D : Male 9th stemite. E: Tegmen. F : Fore leg. G : Hind leg. 
with subbasal and subapical fascicles much smaller than the second one of third interval, three fascicles between them much smaller, seventh and ninth intervals each with 6-8 small fascicles or pustulae, each with a few small scales, first interval with a row of suberect scales, which are blackish in the middle and greyish on declivity.

Prosternal process between coxae $2 / 5$ times the width of mesosternal process, the latter much narrower than base of middle femur. Metasternum between middle and hind coxae $5 / 2$ times the length of first ventrite behind coxa. Abdominal process 5/9 times the width of hind coxa, first ventrite behind coxa as long as second.

Fore and middle femora weakly clavate, hind femora clavate. Tibiae of the same width throughout. Third segment of tarsi shallowly and broadly emarginate at apex.

Female : Unknown.

Length : $5.5 \mathrm{~mm}$.

Holotype ơ (Type No. 2633, Kyushu Univ.), Nakaragawa, Iriomote, 9. x. 1963, S. Kuniyoshi leg.

PARATYPE :10 , Shirahama, Iriomote, 23-24. vi. 1970, H. Makihara leg.

DisTRIBUTION : Japan (Iriomote).

This new species is close to C. endai sp. nov. at first sight in the coloration and size, but is easily separable from it by the scaling of the venter. The name is dedicated to Mr. Seiho Kuniyoshi, the former director and entomologist of the Okinawa Forest Research Station, who collected this interesting weevil for the first time.

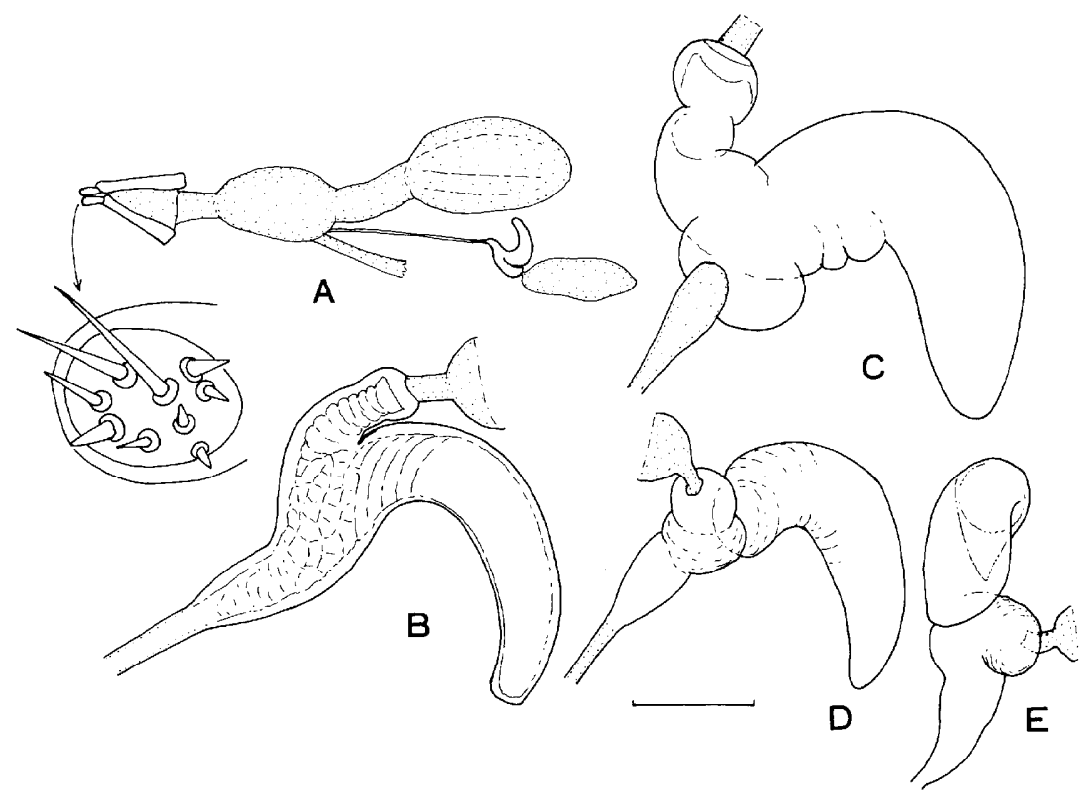

Fig. 10. Female genital organs of Colobodes spp. A, B , C. formosanus Kôno. C : C. alboguttatus sp. nov. D, E : C. endai sp. nov. (B-E : Spermatheca). (Scale $0.1 \mathrm{~mm}$ for spermatheca). 


\section{Deretiosus Pascoe}

Deretiosus Pascoe, 1873, Proc. Linn. Soc. Lond., XI : 184 (type-species: Deretiosus aridus, by monotypy). -Lea, (1908) 1909, Proc. Linn. Soc. N. S. Wales, XXXIII: 707 (Australia). -Lea, (1909) 1910, Proc. Linn. Soc. N. S. Wales, XXXIV : 594 (key). -Heller, 1921, Philipp. J. Sci., XIX : 558 (key). -Lea, 1928, Rec. S. Austr. Mus., IV (1) : 61 (notes; Fiji). -Zimmerman, 1937, Occ. Pap. B. P. Bishop Mus., XIII : 69 (notes ; Fiji). -Zimmerman, 1941, Occ. Pap. B. P. Bishop Mus., XVI : 177 (revision ; = Microbothrus, Deretiosomimus, Lobocodes and Solobrachidius). -Zimmerman, 1942, B. P. Bishop Mus., Bull. 172 : 101 (key ; Guam). - Voss, 1958, Decheniana, Beihefte $5: 50$ (key; China). -Morimoto, 1978, Esakia, (11) : 128 (key).

Microbothrus Fairmaire, 1881, Ann. Soc. ent. Fr., (6)1 : 301 (type-species: Microbothrus squamituber, by monotypy).

Deretiosomimus Heller, 1921, Philipp. J. Sci., XIX : 557, 561 (type- species : Deretiosomimus an gulicollis, by original designation). -Voss, 1937, Tijdschr. Ent., $80: 164$ (Java). -Morimoto, 1978, Esakia, (11) : 128 (key).

Lobocodes Heller, 1921, Philipp. J. Sci., XIX : 558, 569 (type-species: Colobodes turbatus, by original designation).

Locobodes Hustache (sic!), 1936, Col. Cat., 151:67 (= Lobocodes, slip of the pen).

Solobrachidius Voss, 1937, Tijdschr. Ent., $80: 158$ (as a subgenus of Solobrachis ; type-species not designated ; key to spp.)

Pronotum and elytra nodose and fasciculate. Antennae with funicle 7-segmented, first segment about as long as second, club compact, sutures arched. Prothorax edged laterally, with ocular lobes, with a pair of anterior and two pairs of median fascicles. Scutellum tomentose. Elytra fasciculate at least on third, fifth and seventh intervals. Femora not or weakly clavate, dentate. Tibiae weakly but perceptively angulate behind the middle at the inner margin and keeled from the bases to the angles. Tarsi with third segment deeply notched. Seventh tergite in both sexes with scrapers. Prosternum canaliculate and sharply keeled laterally before coxae, metastemal process weakly to
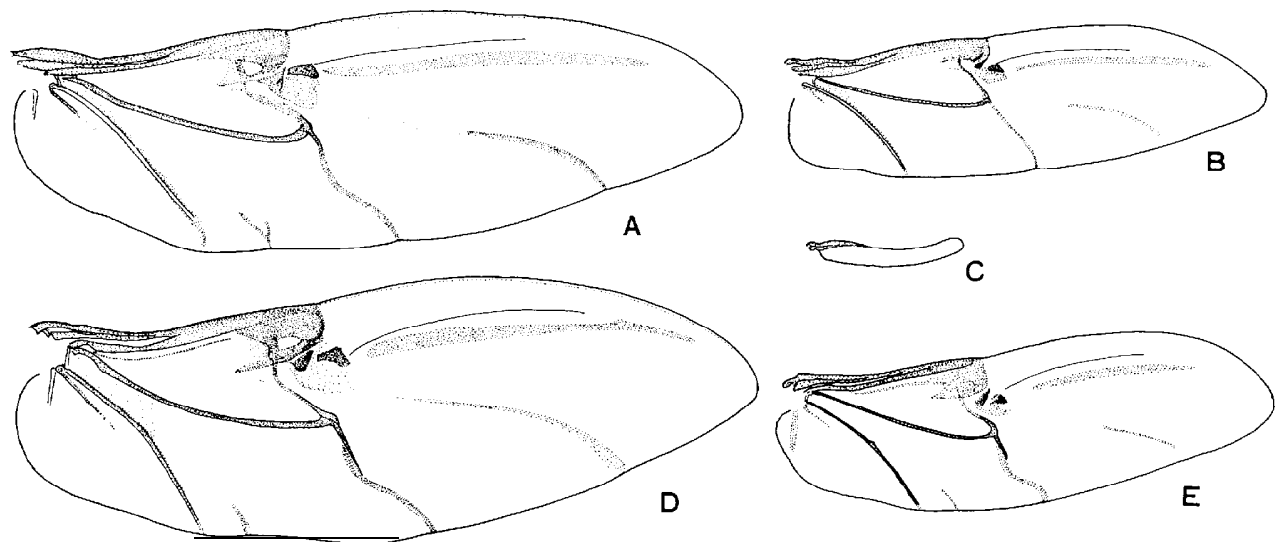

Fig. 11. Hind wings. A : Colobodes konoi Nakane. B : Colobodes endai sp. nov. C: Colobodes rotundicollis sp. nov. D : Deretiosus angulicollis (Heller). E:Deretiosopsis nigrisetis gen. et sp. nov. 
steeply declivous between middle coxae. Hind coxae not actually reaching metepisterna, but narrowly separated by contiguity of metasternum and first ventrite at sides. Male aedeagus with penis sclerotized at lateral and apical margins, less sclerotized at ventral part, which becoming indefinite apically, lateroventral margins scarcely pigmented, parameres paired.

The genus Deretiosus, 35 species at that time, was well revised by Zimmerman (1941), and five species have been described thenceforth. In this paper four species are recorded from Japan for the first time, of which two are new to science.

\section{KeY TO JAPANESE SPECIES}

1(2) Pronotum as long as broad. Each of elytral intervals with a row of long, erect, narrowly spatulate or clavate setae, which are not surrounded by pustulae and scarcely or slightly smaller than those in fascicles. Third interval with three fascicles, subbasal fascicle largest, distant from the base by its width, second fascicle median, a little smaller than the former, both brownish, third fascicle behind the middle small, whitish to grey, fourth fascicle on declivity much smaller and often indefinite, brownish. Length : 5.4-6.0 mm.

Deretiosus ishigakianus sp. nov.

2(1) Pronotum much broader than long. Each of elytral intervals at most with a row of oval short scales surrounded by pustulae, which are much shorter than those in fascicles.

3(4) Third elytral interval with a large subbasal fascicle and two small fascicles or large pustulae in the middle. Subbasal fascicle on fifth interval reduced to a small pustula including one to three scales and not larger than second pustula, second interval in the middle with two and fourth interval at basal third with one distinct pustulae, which are as large as those on third and fifth intervals behind the middle. Scaling predominantly ash grey to dirty grey, with a common rhombic indefinite dark patch in the middle of elytra. Length : $5.0-6.6 \mathrm{~mm}$.

Deretiosus sellatus Heller

4(3) Third interval with subbasal and median fascicles, which are subequal in size and large. Subbasal fascicle on fifth interval distinct, second and fourth intervals at most with minute pustulae.

5(6) Elytra with a reverse W-shaped whitish common patch behind the middle on brownish background. Metastemal process between middle coxae weakly declivous. Length : 5.5-7.2 mm.

Deretiosus angulicollis (Heller)

6(5) Elytra entirely greyish to whitish behind the middle and brownish to dark brownish on basal half with blackish bases of third intervals. Metasternal process between middle coxae steeply declivous. Length : 3.1-4.5 mm.

Deretiosus albicaudatus sp. nov.

\section{KEY TO SPECIES BY THE MALE GENITALIA}

1(2) Penis with a round projection and partly overlapped by the proximal part of internal sac at apex, with an unsclerotized slit on each lateroventral margin. Parameres widely distant.

Deretiosus sellatus Heller

2(1) Penis not projected, but evenly rounded at apex in dorsal aspect, broadly unpigmented at lateroventral margins. Parameres narrowly separated or partly connate at bases.

3(4) Internal sac with a dense setose area and a large spine within the main part of penis.

Deretiosus angulicollis (Heller)

4(3) Internal sac without dense setose area and unarmed. 
5(6) Penis sharply tapered apically in lateral aspect, with small setae at apex.

Deretiosus ishigakianus $\mathrm{sp}$. nov.

6(5) Penis bluntly tapered apically in lateral aspect, without setae at apex.

Deretiosus albicaudatus sp. nov.

\section{Deretiosus angulicollis (Heller)}

(Figs. 11D, 12, 13)

Deretiosomimus angulicollis Heller, 1921, Philipp. J. Sci., XIX : 561 (Luzon : Los Baños).-Voss, 1937, Tijdschr. Ent., $80: 164$ (key ; Luzon: Mt. Makiling).

Deretiosus angulicollis : Zimmerman, 1941, Occ. Pap. B. P. Bishop Mus., XVI : 180, 190, 191 (redescr.; Mt. Makiling, Surigao).

This species is well described in the literatures. The male and female genitalia are as follows :

Male : Seventh tergite broadly and evenly concave at posterior margin, with 15-18 pairs of scrapers, eighth tergite parallel-sided and broadly rounded at apex. Penis broadly rounded at apex,
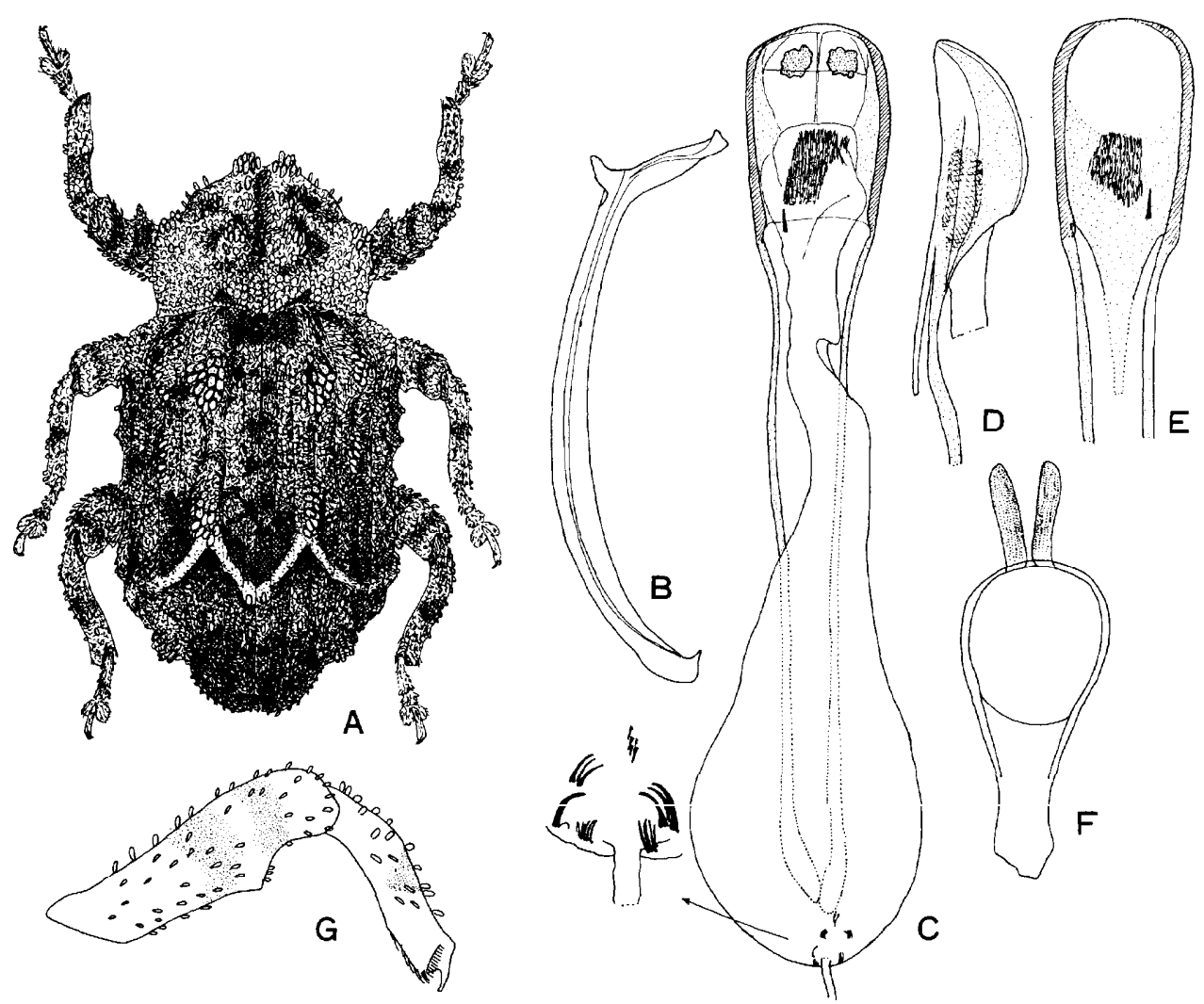

Fig. 12. Deretiosus angulicollis (Heller), male. A : Dorsal aspect. B : 9th sternite. C-E : Penis, dorsal, lateral and ventral aspects. F : Tegmen. G : Hind leg. 
with a pair of sclerites at ostium, internal sac with dense asperities throughout excepting the basal area around gonopore, with three pairs of small setal tufts near gonopore, apical area within the main part of penis with a dense setose area and armed with a stout spine.

Female : Seventh tergite narrowed posteriorly in a weak curve and broadly rounded at apex, with three to four pairs of scrapers, eighth tergite rapidly tapered apically and adorned with many short stout spines, which arranged transversely in a row along apical margin. Bursa copulatrix large, swollen, with irregular rows of spines at the apical part, spermathecal gland with long tubular part.

Specimens eXAmined : 30 specimens from Miyako, Ishigaki and Iriomote Isls., Taiwan (Kenting, Lyuchih, Kuraru), Philippines (Mt. Makiling, Quezon Nat. Park).

Distribution : Japan (Miyako, Ishigaki, Iriomote)-new record, Taiwan-new record, Philippines.

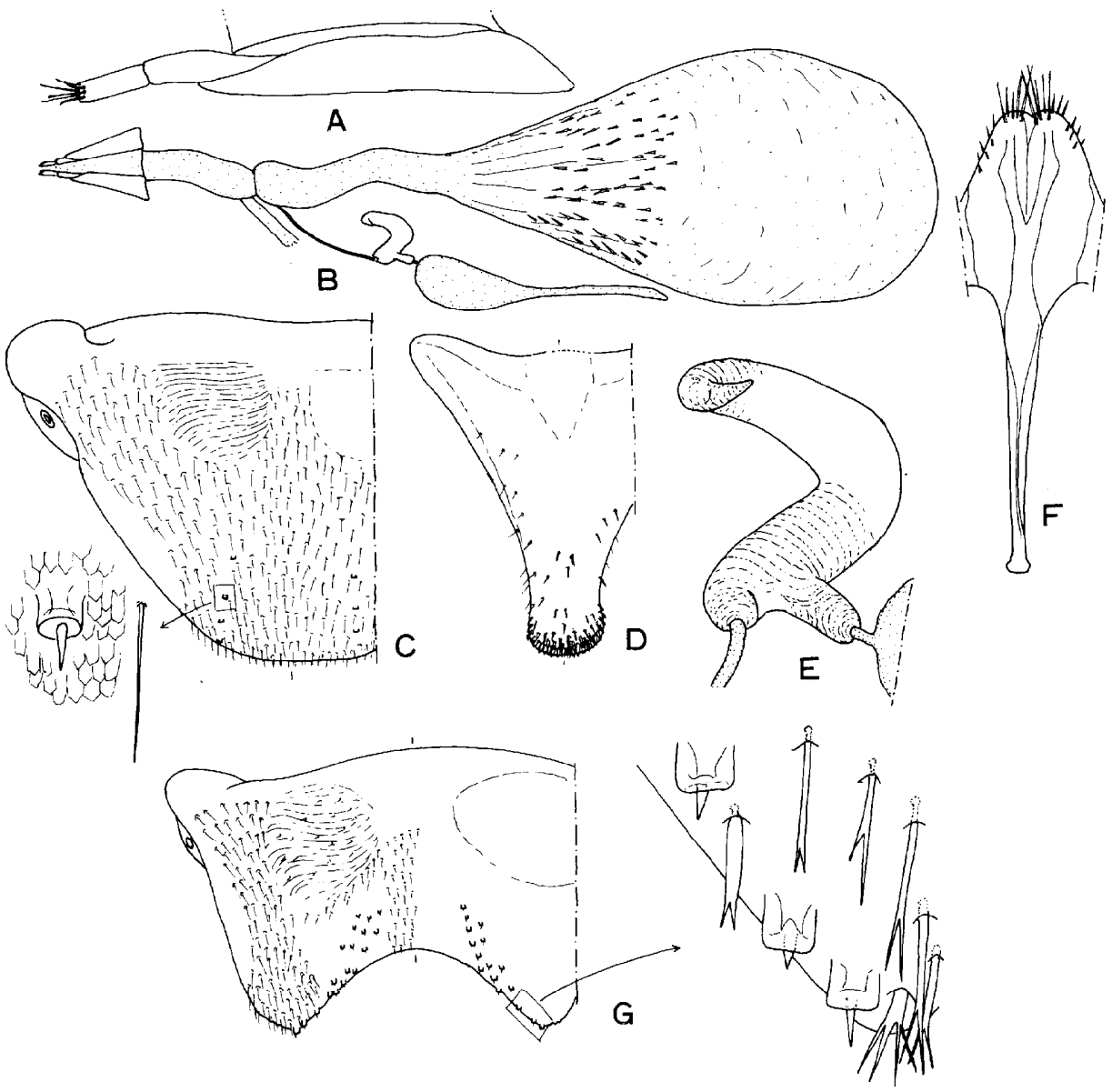

Fig. 13. Deretiosus angulicollis (Heller), A-F: Female. G : Male. A : Hemistemite. B : Genital organ. $\mathrm{C}: 7$ th tergite. $\mathrm{D}: 8$ th tergite. $\mathrm{E}:$ Spermatheca. F: 8th sternite. G : 7th tergite. 


\section{Deretiosus sellatus Heller}

(Fig. 14)

Deretiosus sellatus Heller, 1940, Arb. morphol. taxon. Ent. Berlin-Dahlem, 7 : 100 (Formosa :

Taihorinsho).

Male : Scaling predominantly ash grey to dirty grey, pronotum with a pair of indefinite dark patches, which are often obsolete or often prolonged anteriorly from the base beyond the median fascicles. Elytra blackish on the bases of third intervals before subbasal fascicles, with a common indefinite rhombic dark patch in the middle.

Head with a few short erect scales, forehead between eyes flat, with a few erect scales on each side. Rostrum densely scaled excepting the apex, with scattered small erect scales. Antennae as widely distant from apex as apical width, first segment of funicle as long as second, third and fourth segments as long as broad, fifth to seventh a little broader than long, club twice as long as broad.

Prothorax $3 / 2$ times as broad as long, longitudinally depressed above lateral edges behind lateral fascicles, anterior fascicles with greyish or brownish scales, median and lateral fascicles compact, with greyish or brownish grey scales.

Elytra 1.4-1.5 times as long as broad, parallel-sided on basal half, third interval with a large

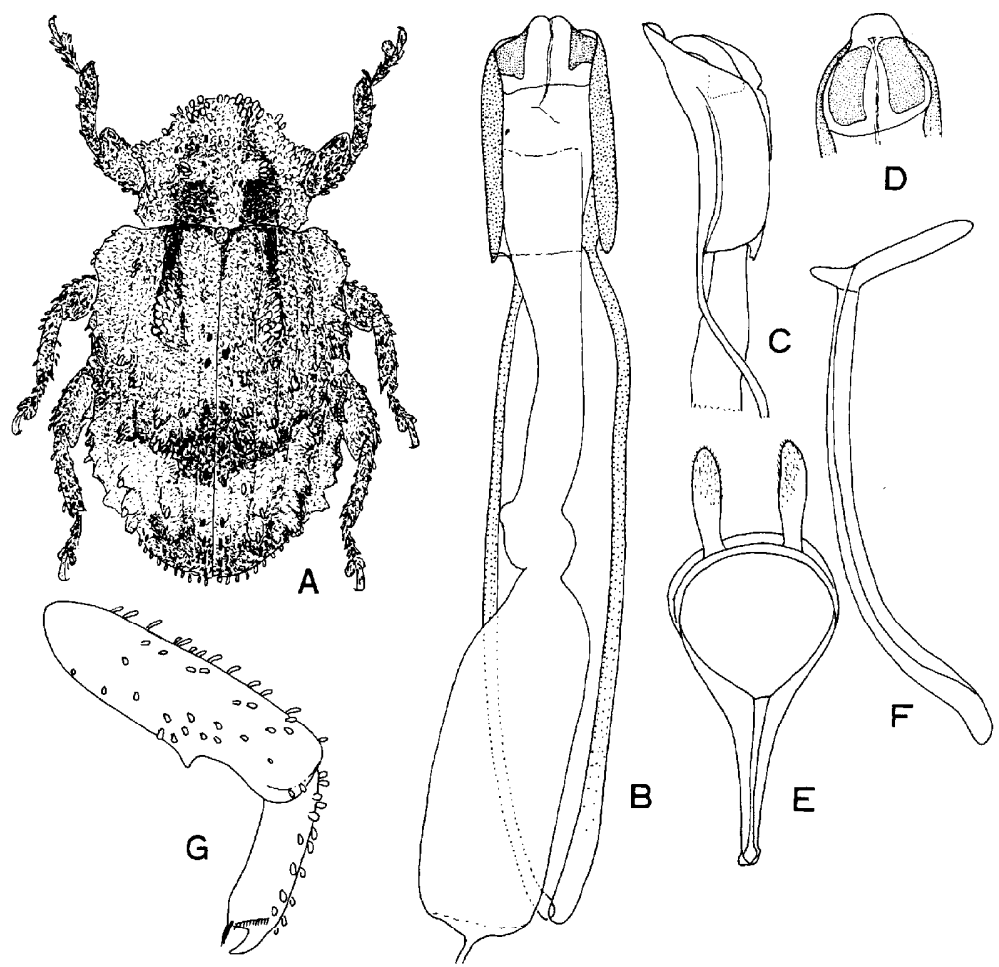

Fig. 14. Deretiosus sellatus Heller, male. A : Male. B, C : Penis, dorsal and lateral aspects. D : Apex of penis. E : Tegmen. F: 9th stemite. G : Hind leg. 
subbasal fascicle, of which the anterior half blackish and the rest greyish, with two median and two postmedian large pustulak bearing an oval scale each, fifth interval with six to seven pustulae, which are usually much smaller than those on third interval, seventh and ninth intervals each with seven small pustulae, second interval in the middle with two and fourth interval at basal third with one distinct pustulae, first interval with a row of about ten erect scales.

Metasternal process between middle coxae steeply declivous. Metasternum between middle and hind coxae shorter than first ventrite behind coxa. Legs robust, femora hardly clavate, slightly compressed at bases, tibiae shorter, angulate internally at apical third.

Seventh tergite with 8-9 pairs of scrapers. Penis roundly projected at apex, proximal part of internal sac at ostium overlapped the apex in dorsal aspect.

Female : Distance between apex of rostrum and antenna1 socket about 1.5 times the apical width. Length : $5.0-6.9 \mathrm{~mm}$.

Specimens eXamined: Akanerindo, Haranomachi, Fukushima Pref., 19, 1. vi. 1980, T. Kinoshita leg. Kueitien, Taitung Hs., Taiwan, 10̛1 1 , 17. vi. 1976, H. Makihara leg. Kenting Park, Pingtung Hs., Taiwan, 19, 17. v. 1978, T. Senoh leg.

DisTRIBUTION : Japan (Fukushima)-new record, Taiwan.

I have also examined the paratype in the British Museum (Natural History).

\section{Deretiosus ishigakianus sp. nov.}

(Fig. 15)

Male : Derm dark reddish brown to blackish, antennae, apex of rostrum, apices of tibiae and tarsi reddish brown, scaling dense, head brownish with greyish margins along eyes, pronotum predominantly greyish, with a pair of dark basal patches, elytra variegated with grey, brown and black, with a zigzag whitish band behind the middle, underside concolorous grey, lateral pieces of meso- and metathoraces brownish grey.

Head with scattered erect small scales, forehead between eyes flat, with a small median fovea, with a few erect scales on each side. Rostrum weakly curved, neither sulcate nor carinate, densely scaled on basal two-thirds, distance between apex and antennal socket 5/7 times the apical width. Antennae with first segment of funicle as long as second, third segment as long as broad, the rest a little broader than long, successively wider distally, club twice as long as broad.

Prothorax about as long as broad, parallel-sided on basal half, then weakly narrowed to subapical constriction, where $4 / 5$ times the width of posterior margin, apical fascicles with loose scales, median fascicles with denser scales, but not compact, lateral fascicles with loose scales, with some additional scales between fascicles and sides, all the erect scales on pronotum narrowly spatulate or weakly clavate. Scutellum rounded, with brownish grey scales. Elytra 10/7 times as long as broad, parallel-sided from humeri to the middle ; third interval with subbasal fascicle large, distant from the base by its width, with brown scales, second fascicle median, a little smaller than the subbasal one, with brown scales, third fascicle behind the middle smaller than the second one, whitish and forming the anterior angle of the zigzag band, fourth fascicle on declivity much smaller, with brown scales, often with one additional small fascicle or large pustula behind that ; fifth interval with five small fascicles, second and fifth ones generally of the same size and as large as the third one on third interval, the other fascicles often smaller and reduced to pustulae bearing one or two scales, subbasal fascicle often reduced to bear a few loose scales ; all interval with a row of subspatulate or weakly clavate erect long scales.

Metasternal process between middle coxae steeply declivous. Metastemum between middle and hind coxae as long as first ventrite behind coxa. Legs relatively slender, femora clavate, tibiae very 


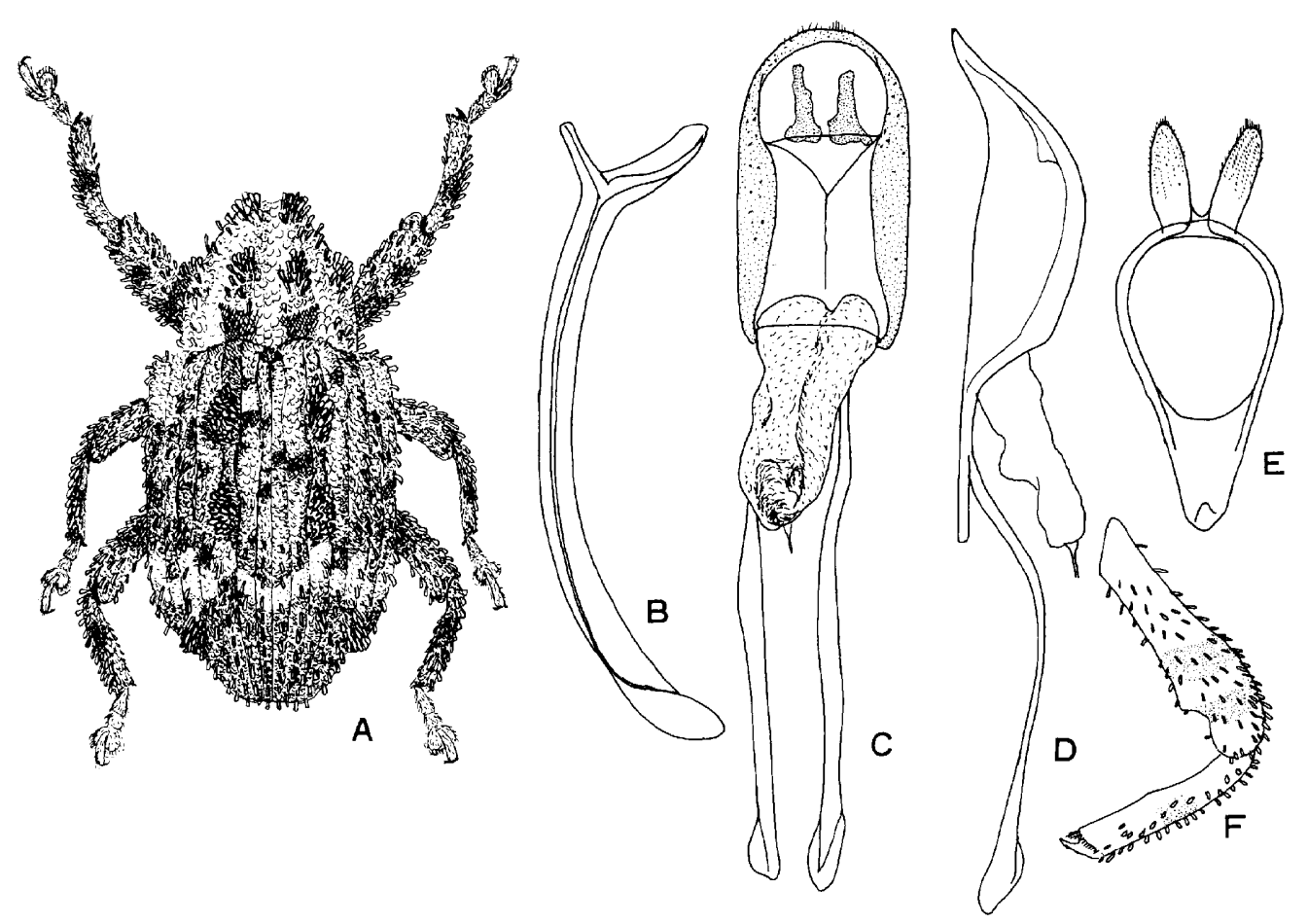

Fig. 15. Deretiosus ishigakianus sp. nov., male. A : Holotype. B : 9th sternite. C, D : Penis, dorsal and lateral aspects. E : Tegmen. F : Hind leg.

weakly angulate internally in the middle. Seventh tergite with three pairs of scrapers. Penis with short setae at apex.

Female : Rostrum scaled at basal third, distance between apex and antenna1 socket 1.3 times the apical width.

Length : 5.4-6.0 mm.

HoLOTYPE $\sigma^{7}$ (Type No. 2634, Kyushu Univ.), Toro-gawa, Ishigaki, 17. iii. 1964, Y. Miyatake leg.

PARATYPES : Same data as holotype, 40 29. Kaarayama, Ishigaki, 10', 14. iii. 1964, Y. Miyatake leg. Hirano, Ishiqaki, 19, 28. iii. 1972, 0. Yamaii leg. Kabira, Ishigaki, 10̛', 26. iii. 1973, I. Matoba leg.

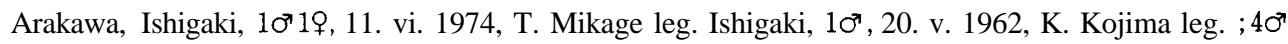
39, 6. iv. 1984, K. Iha leg. Uehara, Iriomote, 10', 28. iii. 1984, N. Nishida leg.

Distribution : Japan (Ishigaki, Iriomote).

This new species is easily distinguished from the others by the following characters : Pronotum as long as broad, each intervals of elytra with a row of long erect scales, elytra with a zigzag band behind the middle.

\section{Deretiosus albicaudatus sp. nov.}

(Fig. 16)

M ale: Derm reddish brown to dark brown, scaling dense, head and rostrum brownish grey, pronotum greyish, with a pair of basal black patches, which often connate internally and forming a 

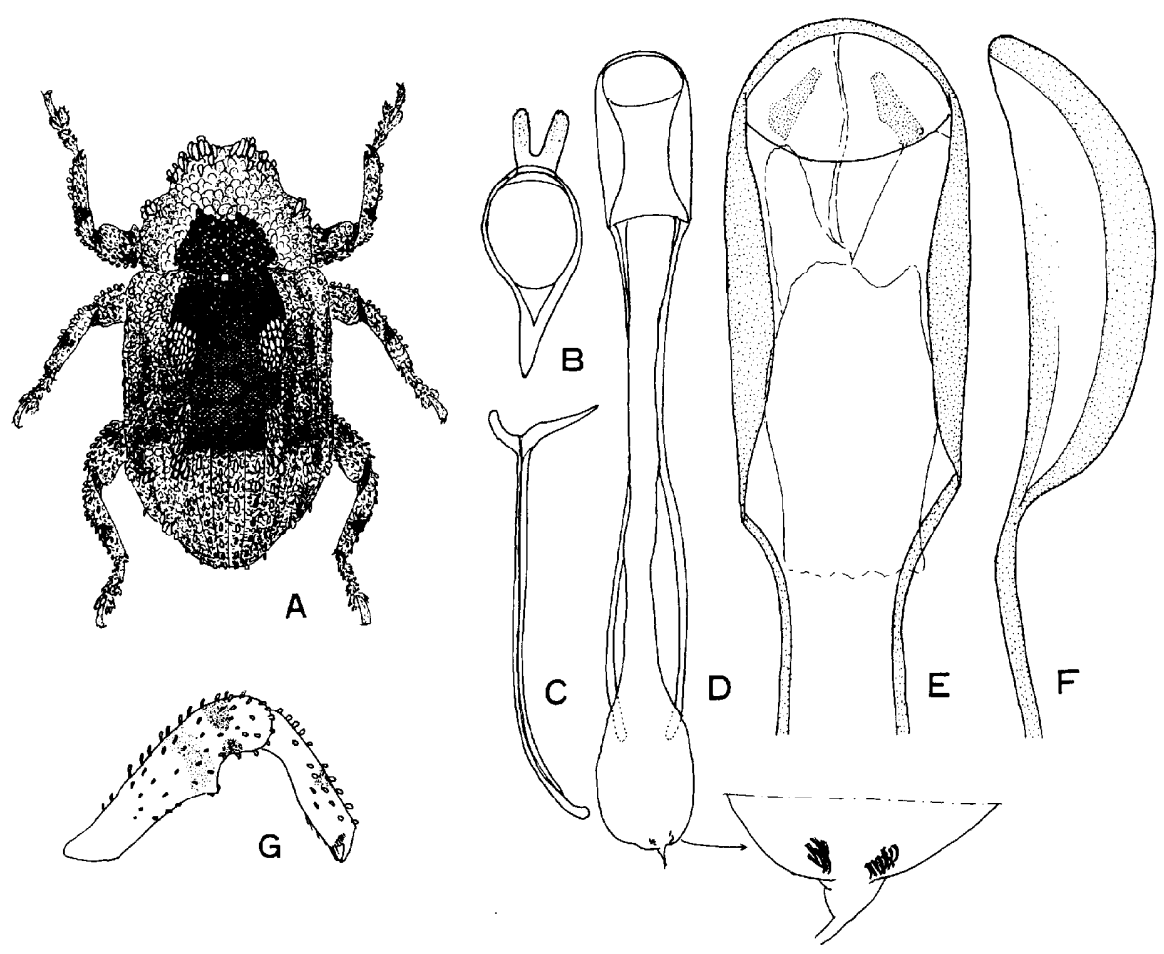

Fig. 16. Deretiosus albicaudatus sp. nov., male. A : Holotype. B : Tegmen. C : 9th sternite.

D-F: Penis, dorsal and lateral aspects:

trapezoid common patch, anterior and lateral fascicles with brownish grey scales, median fascicles with greyish scales mixing some black ones posteriorly, elytra with a basal black stria on third interval including basal third of subbasal fascicle, first two intervals often blackish at base or blackish area expanded posteriorly to the middle, a little more than half of elytra darker or brownish excepting humeri, the apical part distinctly greyish to whitish, underside predorninantly greyish, with brownish apical three ventrites and lateral pieces of meso- and merathoraces in various degrees.

Head and rostrum densely scaled, only with a few erect brownish scales along inner margins of eyes and some at the base of rostrum, forehead between eyes weakly depressed. Rostrum weakly curved, apical area bare and punctate, with a median carina, distance between apex and antennal socket $5 / 7$ times tne apical width. Antennae with first segment of funicle a little longer than second, third segment as long as broad, fourth to seventh segments transverse and successively broader distally, club about twice as long as broad.

Prothorax 1.3-1.4 times as broad as long, parallel-sided from the base to the middle, then angulately narrowed to subapical constriction, anterior fascicles indefinite, with dense scales in the centers and loose ones at margins, median fascicles bicolour, brownish grey with greyish surroundings at anterior half and blackish at the posterior half. Scutellum flat, oval.

Elytra $3 / 2$ times as long as broad, parallel-sided frorn hurneri to the middle ; third interval with subbasal fascicle large, bicolour, basal third blackish, the rest brownish, second fascicle median, almost as long as, but narrower than the subbasal one, mostly brownish to dark brownish with greyish 
posterior margin, fifth interval weakly fasciculate only on subapical swelling, with four pustulae bearing a few scales ; ninth interval costate at posterior margin ; each interval with a row of small suberect oval scales.

Metasternal process between middle coxae steeply declivous. Metasternum between middle and hind coxae as long as first ventrite behind coxa. Femora weakly clavate, tibiae slightly angulate internally in the middle. Seventh tergite with 7-11 scrapers. Internal sac of penis with a pair of setal tufts by gonopore.

Female : Distance between apex of rostrum and antennal socket 1.1 times the apical width.

Length: 3.1-4.5 mm.

Holotype ơ (Type No. 2635, Kyushu Univ.), Mt. Omotodake, Ishigaki, 18-21. iv. 1975, H. Irie leg.

PAratypes : Naha, Okinawa, 36 49, 15. v. 1962, K. Kojima leg. Shuri, Okinawa, lb, 29. v. 1958, 0. Nakachi leg. ; 29, 21. viii. 1961, M. Okabe leg.; lb, 5. v. 1969, H. Makihara leg. Hirara, Miyako, 19, 13. vii. 1968, H. Makihara leg. ; 107, 27. viii. 1968, H. Makihara leg. ;19, 17. viii. 1969, H. Makihara leg. Kawahara, Ishigaki, 3ơ'4일. 23. v. 1962, K. Kojima leg. Yonehara, Ishigaki, 19, 15. iii. 1964, Y. Miyatake leg. Toro-gawa, Ishigaki, 10 , 17. iii. 1964, Y. Miyatake leg. Same locality as holotype, 3 619, 30. viii. 1962, M. Okabe leg. Ishigaki, 10² , 22. v. 1964, K. Kojima leg. Otomi, Iriomote, $29,21$. ix. 1960, K. Yasumatsu leg. ; 19, 25. iv. 1969, H. Makihara leg. Shirahama, Iriomote, 16, 7. iii. 1964, T. Shirôzu leg. ; 29, 8. iii. 1964, S. Kimoto \& Y. Miyatake leg. Funaura, Iriomote, 1ơ , 26. iv. 1977, H. Hiramatsu leg. Yonaguni, 2619, 3. iv. 1980, Y. Sawada leg. Kenting Park, Pintung Hs., Taiwan, 19, 14-19. v. 1979, Y. Kusunoki leg.

DistriBuTION : Japan (Okinawa, Miyako, Ishigaki, Iriomote, Yonaguni), Taiwan.

This species is close to D. ficae Zimmerman from Guam in size and coloration, but the second fascicle on the third interval is much larger and not separated into small fascicles.

\section{Deretiosopsis gen. nov.}

Derm densely covered with thick earthy incrustation except for the apex and underside of rostrum, antennae and tibia1 unci, with long erect scales on pronotum and elytra, which are fasciculate on pronotum and third interval of elytra, when observed on denuded specimens, these scales borne on tubercles, and thin plumules present around scales along anterior and lateral margins of pronotum and basal margins of elytra.

Forehead between eyes as broad as the base of rostrum, weakly depressed, head and rostrum evenly covered with incrustation. Rostrum punctate, with a median keel. Antennae inserted in the apical third in male or the middle in female ; funicle 7-segmented, first segment longer than second, club compact, first segment $3 / 4$ of the whole length. Prothorax strongly constricted, but the constriction completely concealed with incrustation, with weak ocular lobes. Scutellum small, covered with incrustation, Elytra longer than broad, parallel-sided, with ten intervals and nine striae complete, each stria with a row of round punctures, septa between punctures as high as intervals. Prosternum before coxae canaliculate, with sharp edges, mesosternal process not suddenly constricted, but evenly sloped anteriorly in a curve, metasternal process almost vertical and sharply edged between middle coxae, much narrower than middle coxa, inside of the pectoral canal including prosternellum scaled. Metasternal sutures complete. Metasternum between middle and hind coxae as long as first ventrite behind coxa. Abdominal process almost truncate, a little narrower than hind coxa. Metepisternum, hind coxa, first ventrite and metasternum contiguous at a point on each side. First ventrite behind coxa as long as second and slightly shorter than third and fourth combined. Legs stout, femora unarmed, evenly covered with incrustation, not sulcate, tibiae straight, with a bare carina internally, tarsi with third segment deeply bilobed, claws free, of normal size. 
M ale: Seventh tergite transverse, broadly concaved at apex, with six pairs of scrapers, with many plumose scales at sides. Eighth tergite consisting pygidium, with plumose scales. Ninth sternite asymmetrical. Penis with long struts and long internal sac, the latter asperate, with a pair of sclerites at ostium, parameres broadly connate internally.

Female : Seventh tergite consisting pygidium, subtriangular, with rounded apex, with seven pairs of scrapers, with plumose scales at lateral and apical margins. Eighth tergite longer than broad, weakly narrowed apically and subtruncate at apex, with setae at apical area. Ovipositor with a pair of sclerotized hemisternites and styli, bulsa copulatrix very large.

Type species : Deretiosopsis nigrisetis gen. et sp. nov.

This genus is close to Deretiosus, but the related genera can be separable by the following key.

1(4) Antenna1 funicle 6-segmented.

Z(3) Femora not toothed ; third tarsal segment bilobed.

Deretiodes Marshall, 1931

3(2) Femora toothed; third tarsal segment truncate distally and not bilobed.

4(1) Antenna1 funicle 7-segmented.

5(6) Femora toothed ; derm covered with scales, but not with amorphous earthy incrustation.

Deretiosus Pascoe, 1873

6(5) Femora not toothed ; surface structures completely concealed with amorphous earthy incrustation.

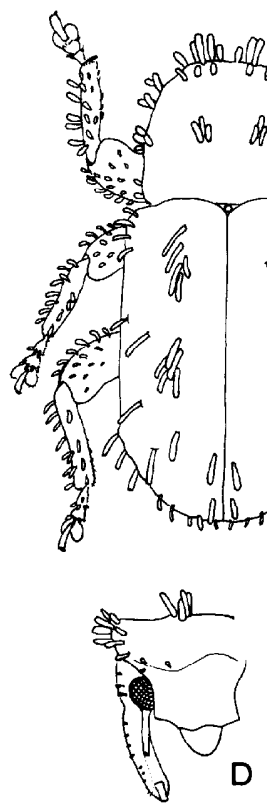

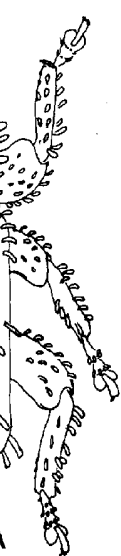

A

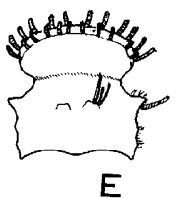

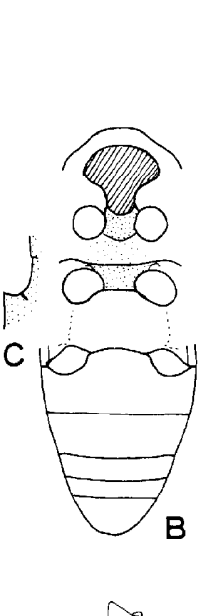
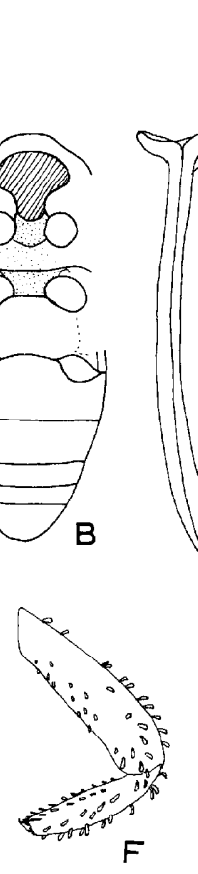

Deretiosopsis gen. nov.

Teleodactylus Marshall, 193 
Deretiosopsis nigrisefis sp. nov.

(Pigs. 11E, 17, 18)

Male : Derm reddish brown, with dense thick earthy incrustation, visibly brownish or earthy grey, with long erect black scales on pronotum and elytra.

Head with sparse fine punctures, which becoming denser and larger between eyes, with a small fovea between eyes, without any erect scales except for a few ones along inner rnargin of eyes. Rostrum almost parallel-sided from base to quarter, then weakly narrowed to the antennal insertions, and weakly dilated apically, with dense punctures and scattered erect small scales, distance between apex and antennak socket $4 / 5$ times the apical width. Antennae with first segment of funicle $4 / 3$ times as long as second, third segment as long as broad, fourth to seventh segments a little broader than long, successively wider distally, club compact, $3 / 2$ times as long as broad.

Pronotum as long as broad, with a strong median and two weak postmedian tubercles on each side, deeply constricted before the rnedian tubercles at sides, but shallowly depressed dorsally, median tubercles weaker than the median lateral ones, disk thinly with small punctures, without median carina, anterior margin with irregular two rows of erect scales, usually 22 to 30 in number, median fascicles each with 3-5 erect scales, lateral fascicles each with 2-3 scales in median one and a scale in postmedian one.

Elytra about 1.5 times as long as broad, parallel-sided from humeri to the middle, third interval with subbasal fascicle consisting of 4-6 scales, median fascicle with 4-6 scales, third fascicle with a scale, these fascicles lying on tubercles, first interval with four erect scales on apical third from the

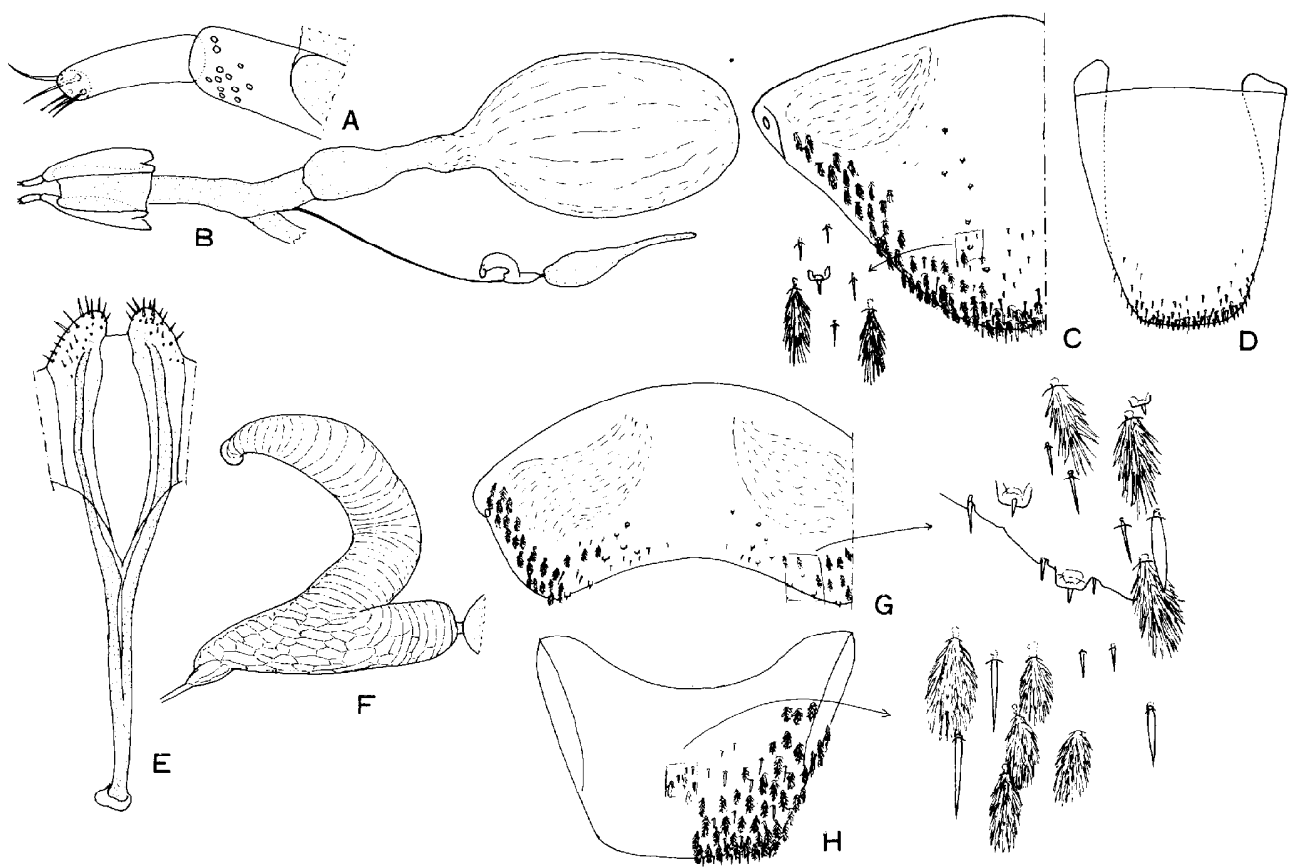

Fig. 18. Deretiosopsis nigrisetis gen. et sp. nov. A-F : Female. G-H : Male. A : Apex of ovipositor. B : Genital organ. C : 7th tergite (pygidium). D : 8th tergite. E : 8th sternite. F : Spermatheca. G : 7th tergite. $\mathrm{H}:$ 8th tergite (pygidium). 
top of declivity to the apex, fifth interval with three erect scales from the middle to subapical swelling, seventh interval with a few erect scales at humeral callus, and further with three scales from the middle to subapical swelling, apical margin with several greyish small scales.

Penis tapered apically, with unpigmented lateroventral areas.

Female : Rostrum slender, with a fine median carina, distance between apex and antenna1 socket $6 / 5$ times the apical width.

Length : 2.7-4.5 mm.

HoLotype ơ (Type No. 2636, Kyushu Univ.), Hiji, Okinawa, 3. vii. 1974, T. Mikage leg.

ParatyPES : Miike, Takaharu, Miyazaki Pref., 10̛4요, 16-18. v. 1983, Y. Sawada leg. Aoshiodake, Shimokoshiki-jima, Kagoshima Pref., 19, 20. vi. 1970, H. Irie leg. Mt. Yuwan, Amami-Oshima, $2 \sigma^{\prime}, 30$. vii. 1963, L. Gressitt leg. Nishinakama, Amami-Oshima, 16, 1. vi. 1970, H. Makihara leg. Maruhata, Sumiyo-son, Amami-Oshima, 10 , 7. iv. 1977, T. Ogasawara leg. Same data as holotype, 3ơ 4 q

Distribution: Japan (Kyushu, Amami-Oshima, Okinawa).

Description was partly made on the denuded specimens. In the most thickly covered specimens, the pronotum is visibly rounded as in fig. 17A, but the subapical constriction is more or less distinct in general according to the thickness of the incrustation.

\section{Referenees}

Desbrochers des Loges, M. J., 1891. Curculionides et Brenthides du Bengale occidental recueillis par le K. P. Cardon avec description d'espèces nouvelles. Bull. Soc. ent. Belg., XXXV, Compt.-rend.: cccl-ccclxi.

Fairmaire, L., 1881. Essai sur les Coléoptères des îles Viti (Fidji). Ann. Soc. ent. FY., (6)1 : 242318.

Faust, J., 1892. Curculioniden aus dem malayischen Archipel. Stett. ent. Ztg., 53 : 184-228.

-, 1893. Notizen über Rüsselkäfer. Stett. ent. Ztg., 54: 145-152.

- , 1895. Viaggio di Leonardo Fea in Birmania e regioni vicine. LX. Curculionidae. Ann. Mus. Civ. Stor. Nat. Genova, (2) XIV(XXXIV): 153-370.

- 1898. Beschreibung neuer Coleopteren von Vorder-und Hinterindien aus der Sammlung des Hrn. Andrews in London, II. Deut.ent. Zschy., 1898 : 273-333.

-, 1899. Viaggio di Lamberto Loria nella Papuasia orientale, XXIII. Curculionidae. Ann. Mus. Civ. Stoy. nat. Genova, XL: 1-130.

Heller, K. M., 1921. New Philippine Coleoptera.Philipp. J. Sci., 19:523-625, 3 pls.

—, 1923. Neue Philippinische Käfer. Stett. ent. Ztg., 84: 3-24.

—, 1925. Rüsselkäfer von Sumatra gesammelt von Herrn J. B. Corporaal. Zool.Meded., VIII : 220-244.

- 1937. Coleoptera Javana, mit Berücksichtigung der ihnen nahestehenden Formen anderer Herkunft. Stett. ent. Ztg., 9\%:51-78, 1 pl.

—, 1940. Indomalayische Rüsselkäfer II. Ayb. morphol.taxon. Ent. Berlin-Dahlem, 7 : 9'2-113, Taf. 2 .

Hustache, A., 1936. Coleopterorum Catalogus, pars 151, Cryptorrhynchinae, 317 pp. (s'Gravenhage). Kôno, H., 1932. Elf neue Curculioniden aus Japan. Ins. Mats., VI : 92-113, Taf. 2.

—, 1936. Die Käfer-Fauna vom Daisersu Gebirge. Trans. biogeogy. Soc. Jap., 1: 75-104, pl. X.

Lacordaire, T., 1866. Geneya des Coléoptères, VII. 620 pp. (Paris).

Lea, A. M., 1909(1908). Revision of the Australian Curculionidae belonging to the subfamily Cryptorhynchides. Part IX. Proc.Linn.Soc. N ew South Wales, XXXIII : 701-732.

-, 1913. Notes on Cryptorhynchides (Coleoptera, Curculionidae) in the South Australian 
Museum with descriptions of new species. Trans. R. Soc. South Austr., XXXVII : 182-300.

- 1928. Cryptorhynchides (Curculionidae) mostly from Australia. Rec. South Austr. Mus., IV : 49-90.

-, 1931. Australasian Coleoptera. Rec. South Austr.Mus., IV : 365-407.

Marshall, G. A. K., 1915. Report on the Coleoptera collected by the British Ornithologist's Union Expedition and the Wollaston Expedition in Dutch New Guinea. Part II : Curculionidae. Trans. zool. Soc. Lond., XX : 509-533, pl. XXXIX.

- 1926. New Curculionidae from the Malay archipelago. Philipp.J. Sci., 30 : 349-359.

- - 1930. New Curculionidae, with notes on synonymy. Ann. Mag. nat. Hist., (10) VI: 551-577.

- 1931 . Curculionidae. Insects of Samoa, 4(5) : 249-346.

- 1936. Curculionidae attacking cultivated plants. Bull. ent. Res., 27 : 253-259.

- 1952. Taxonomic notes on Curculionidae. Ann. Mag. nat. Hist., (12)V : 261-270.

Morimoto, K., 1962. Key to families, subfamilies, tribes and genera of the Superfamily Cur culionoidea of Japan excluding Scolytidae, Platypodidae and Cossoninae. J. Fac.Agr., Kyushu Univ., 12: 21-66.

- $\quad$ 1962. Preliminary check list of the families Curculionidae (II) and Rhynchophoridae of Japan. Sci. Bull. Fac. Agr., Kyushu Univ., 19 : 341-368.

-.., 1963. Preliminary notes on the Curculionid fauna of the Yaëyama Group. Report of the Committee on Foreign Scientific Research, Kyushu Univ., (1) :107-116, pl. II.

—, 1978. On the genera of Oriental Cryptorhynchinae. Esakia, (11): 121-143, 62 figs.

-_, 1984. Coleoptera of Japan in color, IV. 438 pp., 72 pls. (Hoikusha Publ. Co., Osaka).

Nakane, T., 1963. New or little-known Coleoptera from Japan and its adjacent regions. XX. Fragm. Coleopt., (8-10): 31-40.

- 1963. Iconographia insectorum japonicorum colore naturaliedita, II. 443 pp., 192 pls. (Hokuryukan, Tokyo).

Pascoe, F. P., 1873. Contributions toward a knowledge of the Curculionidae, part II. J. Linn. Soc. Lond., Zool., XI : 154-218, pls. IX-XI.

- 1873. Contributions toward a knowledge of the Curculionidae, part III. J. Linn. Soc. Lond., Zool., XI : 440-492, pls. X-XIII.

-, 1882. Descriptions of some new genera and species of Curculionidae, mostly Asiatic. Ann. Mag. nat. Hist., (5)X : 443-455, pl. xviii.

Roelofs, W., 1875. Curculionidae recueillis au Japon par M. G. Lewis, 3" partie. Ann. Soc. ent. Belg., XVIII : 149-193, 3 pls.

Schoenherr, C. J., $\quad 1837$. Genera et species Curculionidum. IV. 1121 pp. (Paris).

-, 1845. Genera et species Curculionidum. VIII(1). 341 pp. (Paris).

Voss, E., 1937. Ein weiterer Beitrag zur Kenntnis der Curculioniden Javas. Tijdschr.Ent., 80 : 126166, 4 figs.

- 1958. Fin...Reitrag zur Kenntnis der Curculioniden im Grenzgebiet der Orientalischen zur Paläarktischen Region. Decheniana, Beihefte 5 : 1-139.

- 1960. Die von Biró auf New Guinea aufgefundenen Rüsselkäfer, III. Ann. Hist.-nat. M us. nat. Hung., 52: 313-346.

Zimmerman, E. C., 1937. On Lea's Fijian Deretiosus. Occ. Pap. B. P. Bishop Mus., XIII : 67-73.

—, 1938. Four new Solomon and Caroline Island Deretiosus. Proc. Hawaii. ent.Soc., 10 : 159-164.

- 1941. A revision of the genus Deretiosus.Occ. Pap. B. P. Bishop Mus., XVI': 177-214.

_ 1942. Curculionidae of Guam. B. P. Bishop Mus. Bull., $172:$ 73-146, 7 pls. 